\title{
Toward a Long-Term Strategy of Economic Development of Croatia: Where to Begin, What to Do, and How to Do It?
}

Mihaljek, Dubravko

Source / Izvornik: Occasional Paper Series, 2001, 5, 1 - 38

Journal article, Published version

Rad u časopisu, Objavljena verzija rada (izdavačev PDF)

https://doi.org/10.3326/ops.11

Permanent link / Trajna poveznica: https://urn.nsk.hr/urn:nbn:hr:242:016172

Rights / Prava: Attribution-NonCommercial-NoDerivatives 4.0 International/ImenovanjeNekomercijalno-Bez prerada 4.0 međunarodna

Download date / Datum preuzimanja: 2023-04-26

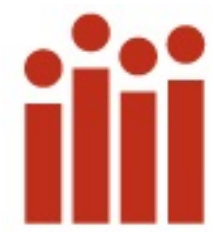

Repository / Repozitorij:

Institute of Public Finance Repository

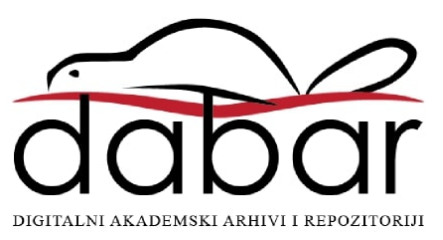


TOWARD A LONG-TERM STRATEGY

OF ECONOMIC DEVELOPMENT OF CROATIA:

WHERE TO BEGIN, WHAT TO DO, AND HOW TO DO IT?

Dubravko Mihaljek

Occasional Paper No. 11

June 2001 


\section{CONTENTS}

I. INTRODUCTION AND SUMMARY 4

II. WHERE TO BEGIN?

Development Potentials and Weaknesses of the Croatian Economy

$\begin{array}{ll}\text { Size of the economy and degree of development } & 7\end{array}$

Leadership commitment to economic development and social capital $\quad 8$

$\begin{array}{lr}\text { Human capital and technology } & 10\end{array}$

$\begin{array}{lr}\text { Economic policy } & 12\end{array}$

$\begin{array}{ll}\text { Institutions, productive capital and physical infrastructure } & 14\end{array}$

III. WHAT TO DO, AND HOW TO DO IT? 18

Basic principles for Croatia's development strategy $\quad 18$

$\begin{array}{ll}\text { Define a clear development objective } & 18\end{array}$

Ensure equal access to development opportunities $\quad 19$

$\begin{array}{ll}\text { Adjust to globalisation and the new economy } & 19\end{array}$

Reform the labour market $\quad 20$

Develop the financial markets $\quad 22$

$\begin{array}{ll}\text { Restructuring the banks and corporations } & 23\end{array}$

Solving the problem of payment arrears $\quad 23$

$\begin{array}{ll}\text { Replacing the national currency? } & 24\end{array}$

Role of foreign direct investment $\quad 25$

Define the role of the state in the economy 25

$\begin{array}{ll}\text { Education } & 26\end{array}$

Rule of law $\quad 26$

Health care, infrastructure, science, technology $\quad 27$

$\begin{array}{ll}\text { Maintain macroeconomic stability } & 28\end{array}$

$\begin{array}{lr}\text { Exchange rate and monetary policy } & 28\end{array}$

$\begin{array}{ll}\text { Tax and investment policy } & 30\end{array}$

IV. AN ILLUSTRATIVE SCENARIO OF LONG-TERM GROWTH 31

REFERENCES: $\quad 35$ 


\title{
Toward a Long-Term Strategy of Economic Development of Croatia: Where to Begin, What to Do, and How to Do It? ? $^{1}$
}

\author{
Dubravko Mihaljek* \\ Bank for International Settlements, Basel
}

\author{
Dubravko.Mihaljek@bis.org
}

\begin{abstract}
This paper attempts to elaborate the main principles of an economic development strategy suitable for Croatia over the next 10-15 years. Based on brief analyses of advances made in development theory and policy and experiences of the emerging market economies in Asia, Latin America, and Central Europe, the paper identifies critical factors necessary for launching an accelerated process of economic development. These factors are: leadership commitment to economic development; the level and quality of social and human capital; application of modern (especially information) technology; stable and consistent macroeconomic policies; and efficient market-based institutions. The paper then analyses Croatia's strengths and weaknesses in terms of these factors in comparison with a select group of economies: Slovenia, Hungary, the Czech Republic, Portugal, Ireland, Chile, Uruguay, Hong Kong and Singapore. In addition, the paper analyses implications of "new economy" developments in the United States and other advanced industrial countries for a small open economy like Croatia.

Against this background, the paper proposes seven basic principles for elaborating a long-term strategy of Croatia's economic development: (i) Setting a clear development goal-the paper proposes a doubling of real per capita GDP to US\$10,000 in the next 10-15 years, which would require an average annual growth rate of about $5 \frac{1}{2} \%$, and that this growth rate is achievable; (ii) Ensuring transparency and equal access to development opportunities, as opposed to following specific industrial policy; (iii) Adjusting to globalisation of economic activity and absorbing "new economy" developments; (iv) Implementing fundamental reform of labour markets, with a view to reducing the high non-wage labour costs through pension and health care reforms; (v) Actively promoting financial market development by accelerating corporate and bank restructuring, and legal and judicial system reforms; (vi) Deciding on the economic role of the state in such areas as education, legal and judicial systems, market regulation, infrastructure, and science and technology; and (vii) Maintaining stable and consistent macroeconomic policies to facilitate structural reforms. The paper briefly discusses the main benefits and costs of a possible "euroisation" of Croatia's economy, and arrangements for a possible transition from the current monetary and exchange rate regime, characterised by a high degree of factor and commodity price indexation to the Deutsche mark, toward a more flexible interim regime that would facilitate the eventual adoption of the euro and be consistent with the overall development strategy outlined.
\end{abstract}

\section{JEL Classification: O10, P20, E60, L52}

Key words: economic development, economic growth, new economic paradigm, globalisation, information technology, emerging market economies, transition economies, macroeconomic policies, industrial policy, corporate and bank restructuring, labour market reform, financial market development, exchange rate policy, eurisation.

\footnotetext{
${ }^{1}$ The longer version of this article was published in Croatian in the journal "Financijska teorija i praksa", Volume 24, Number 4/ 2000, pp. 527-603.

* On leave from the International Monetary Fund. The opinions expressed here are the author's personal views and do not necessarily represent the standpoints of the BIS or the IMF, and are not binding upon them in any way. I would like to thank Dr Ante Čičin-Šain for encouragement during the writing and for many useful suggestions and expert comments, which have very considerably improved the quality of this work. I would also like to thank Katarina Ott, Goran Radman, Bruno Schönfelder and other colleagues for their professional commentaries. The viewpoints of commentators are not necessarily at one with those of the author.
} 


\section{INTRODUCTION AND SUMMARY}

The issue of how to set out the long-term economic development strategy arose soon after political power changed hands in Croatia at the beginning of 2000. However, debates to date have shown a fair amount of desultoriness and inability to cope even with the basic approach to this issue. Is it better first to lay out a vision of long-term development, or is the rapid emergence from stagnation and unemployment the main priority? Should exports be stimulated across the board, or should incentives be provided to selected industries? Are the last ten years a complete loss as far as the economy is concerned, or have some useful reforms, necessary to get out of the transitional vale of tears, been implemented after all? This paper attempts to clarify some of these issues and proposes an approach to elaborating a long-term strategy of economic development of Croatia.

The question Where to begin? is approached from three different angles. First, the theory and policy of economic development are reviewed and, based on post-war experiences of upper-middle income economies, some critical factors necessary to launch and sustain the process of rapid development are derived. Second, the main developmental strengths and weaknesses of the Croatian economy are identified and compared with a diverse group of emerging market economies. Third, the latest global economic trends are analysed, in particular, the spread of the new economy, so as to envision the likely structural changes in the global economy in the next decade or so. ${ }^{2}$

After settling on a starting point for the development strategy, the questions What to do? and How to do it? are addressed. The main findings of this analysis are as follows.

- Croatia can double its real per capital GDP to about $\$ 10,000$ in the next 10-15 years if it achieves an average annual growth rate of 5-6\%. Although this goal is ambitious, an analysis of the recent growth performance of Croatia and similar economies indicates that it is achievable.

- The balance sheet of Croatia's development potentials and weaknesses is not impressive. The main potentials include: technically well-educated labour force, relatively strong industrial tradition, macroeconomic stability, solid physical infrastructure, and natural resources suitable for tourism. Key weakness are: unclear development priorities, large number of interest groups, lack of managerial and organisational skills, unfavourable demographic trends, obsolescent productive capacity, low penetration rate of information technology, lack of entrepreneurial culture, and underdeveloped financial markets and institutional infrastructure, especially the legal system and the judiciary.

- Based on accumulated knowledge and international experience, it seems possible to elaborate a long-term development strategy that has a relatively high probability of success. By contrast, tinkering with some idiosyncratic model of development would seem to have a low probability of success. The factors identified in the literature that seem critical to launch and sustain a rapid process of development include: leadership commitment to economic development, human capital, social capital conducive to growth, stable and consistent macroeconomic policies, good physical infrastructure, and functioning institutions of market economy. Modern technology and other traditional factors of production - land, natural resources, sources of energy and financial capital - are less critical.

- The revolution in information technology has set off deep changes in the organisation and structure of production. The capacity for geographical specialisation in the production of goods and services has significantly increased, and the concept of comparative advantage can no longer be applied to whole industries but to components and parts of the production process. For this reason, there is no future in promoting Croatia's "national industries" like shipbuilding, engineering and shipping. Similarly, because of economic integration and the

\footnotetext{
${ }^{2}$ The discussion of development theory and policy, recent development experiences of the emerging market economies, and the new economy are omitted from this occasional paper, as they were aimed mainly at familiarising the Croatian public with these topics.
} 
communications revolution, a remarkable homogenisation in consumer preferences has arisen, and there is no essential difference between production for the domestic or the export market. The domestic manufacturing and service industries in all sectors simply have to produce efficiently quality goods and services to be able to survive in today's economic environment. This can only be achieved by linking up with successful foreign and domestic companies and adjusting to the requirements of customers.

- The government can do very little by means of macroeconomic and development policies to assist the industry in the adjustment to efficient production in a globalised economy. In particular, the experiences of the emerging market economies in Asia and Latin America have shown that it is mistaken to reduce the problem of economic development to the question of industrial policy. Government policies should be primarily enabling in nature, aimed at inputs rather than outputs, local rather than national in character. In particular, government policies should be focused at increasing the skills and human capital of workers, fostering the production and commercialisation of knowledge, facilitating mobility of workers and their ability to start new firms, and raising the efficiency of the key institutions of market economy: the legal system and the judiciary, the financial system and financial supervision, the tax system and social security, and market competition.

- With the emergence of shareholder value as the basic organising principle of modern firms, the traditionally close links between banks and companies have started to weaken. Investment financing is thus increasingly provided outside the banking system, by issuing bonds, shares and attracting venture capital.

- Significant changes are also taking place in the labour market: compensation is increasingly based on individual performance rather than collective contract, labour legislation is becoming more flexible, and it is easier for employers to both hire and fire. The Croatian economy will not be able to avoid these changes and will have to start restructuring its capital and labour markets as soon as possible with the aim of encouraging - rather than hindering - the development of entrepreneurship, productivity and profitability.

- There are no short-cuts in solving the problems of economic stagnation and high unemployment - the only effective solution is to improve competitiveness of the real sector of the economy. Government can contribute to this goal by maintaining macroeconomic stability, ensuring the rule of law, deregulating product and factor markets, restructuring and selling off the state-owned enterprises to foreign strategic investors, and fostering the growth of a completely new private sector. These processes cannot be started overnight but once they are launched the positive effects in terms of economic growth and a rise in employment follow quickly.

- Despite the widespread belief by the Croatian public and media, the Croatian economy currently is not in a deep a crisis, but rather in a recession caused by structural problems. In this situation, expansionary macroeconomic policies, which are often advocated, would only deepen the structural problems without solving them. In particular, any sudden change in the exchange rate would be damaging because of the prevalent use of financial contracts with liabilities indexed to the exchange rate.

Against this background, the paper proposes seven basic principles for elaborating a long-term strategy of Croatia's economic development. This approach is chosen over the more widespread practice of cataloguing all developmental problems and offering possible solutions because it enables policy makers to decide, in a consistent and analytically sound manner, on various issues that will confront them in elaborating and implementing the strategy. These principles are:

i) Setting a clear development goal - the paper proposes a doubling of per capita real GDP to US $\$ 10,000$ in the next $10-15$ years, and provides some preliminary evidence that the growth rate required to reach this goal (about $5 \frac{1}{2} \%$ per year) is achievable;

ii) Ensuring transparency and equal access to development opportunities, as opposed to following specific industrial policy;

iii) Adjusting to globalisation of economic activity and absorbing new economy developments; 
iv) Implementing fundamental reform of labour markets, with a view to increasing the flexibility of labour markets and reducing the high non-wage labour costs through pension and health care reforms;

v) Actively promoting financial market development by accelerating corporate and bank restructuring, developing indirect instruments of monetary policy, and implementing legal and judicial system reforms;

vi) Clearly defining the economic role of the state in such areas as education, legal and judicial systems, market regulation, infrastructure, and science and technology; and

vii) Maintaining stable and consistent macroeconomic policies to facilitate structural reforms.

The remainder of this paper is divided into three chapters. Chapter II looks at the main developmental potentials and weaknesses of the Croatian economy. Chapter III elaborates the above basic principles for a development strategy. The concluding chapter shows that the Croatian economy can attain under reasonable assumptions a long-term rate of growth rate of 5-6\% per year. 


\section{WHERE TO BEGIN?}

\section{Development Potentials and Weaknesses of the Croatian Economy}

This chapter analyses a variety of economic and social indicators in order to determine the relative position of Croatia as compared with similar economies. Such analysis is essential to settle on a starting point for a development programme, and to assess the main constraints and opportunities for future development. The comparator countries are similar in size of the economy (Slovenia, Uruguay), the level of development (Hungary, Czech Republic, Chile) and historical circumstances under which their development was launched (Portugal, Ireland, Hong Kong and Singapore). Although many of these countries are located in different geographical regions and have a different cultural and political heritage, such broader comparisons are useful because they provide a better insight into Croatia's development potential. ${ }^{3}$ The indicators used to assess the development potential are grouped under four main headings: leadership commitment to development and social capital; human capital and technology; economic policy; and institutions, productive capital, physical infrastructure and natural resources.

\section{Size of the economy and degree of development}

In terms of size, Croatia is among the smaller economies, with a GNP of \$21 billion in 1998. Because of a large number of poor and island states, Croatia is still in the upper third of countries in terms of size of the economy. ${ }^{4}$ Most similar in this respect are Kazakhstan, Uruguay, Slovakia and Slovenia (Figure 1).
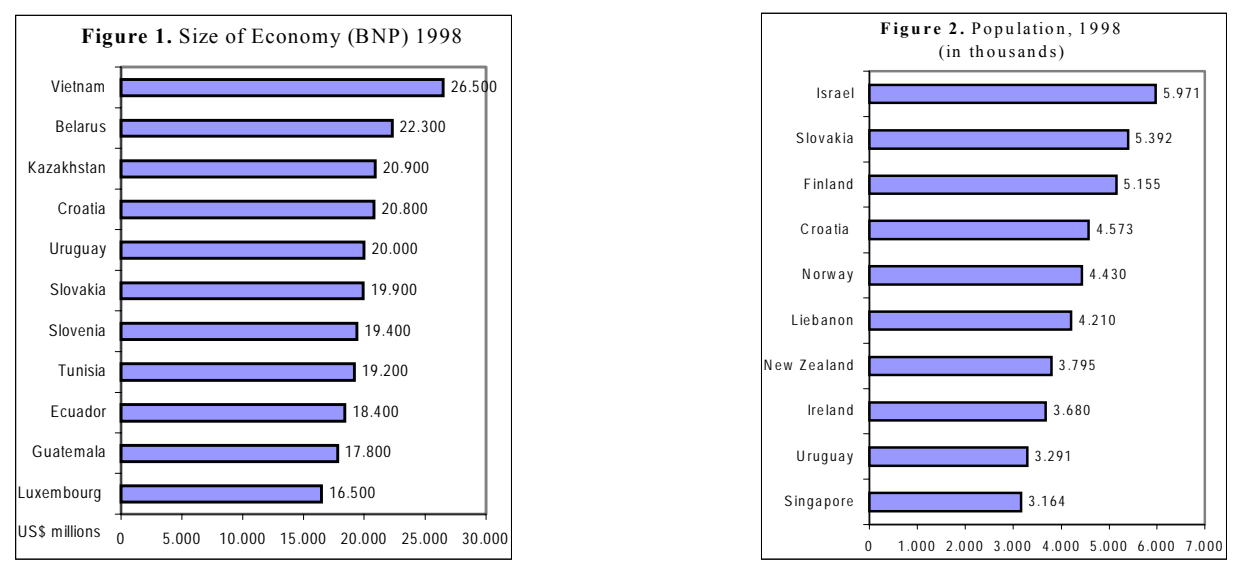

Sources: World Bank, World Development Report 1999/2000, and World Development Indicators 2000.

By population size, Croatia is a small country. With its 4.6 million inhabitants as of mid-1998, Croatia is at $112^{\text {th }}$ place of the 210 countries ranked. Most similar in terms of population size are Finland, Norway and Lebanon (Figure 2).

\footnotetext{
${ }^{3}$ Structural economic characteristics do not depend on geographical and cultural features and change over the long term. Development policy therefore has to treat the economic structure as an endogenous variable, rather than fall into historical determinism. A typical example of the latter approach is Berend (2000), who argues that countries in transition will always stay on the periphery of Europe because their per capita GNP has been unchanged at about $40 \%$ of per capita GNP of Western Europe for the past 130 years.

${ }^{4}$ Evaluated in terms of purchasing power parity, Croatia's GNP is higher ( $\$ 22.8$ billion), but its relative position on the scale is lower $\left(84^{\text {th }}\right.$ place instead of $66^{\text {th }}$ of the total of 170 countries ranked).
} 
In terms of degree of development, Croatia is among the countries with upper middle income. In 1998, Croatia's per capita GNP was about $\$ 4,620$, about the same as in Hungary and Brazil, but a half of that of Slovenia and Portugal (Figure 3).

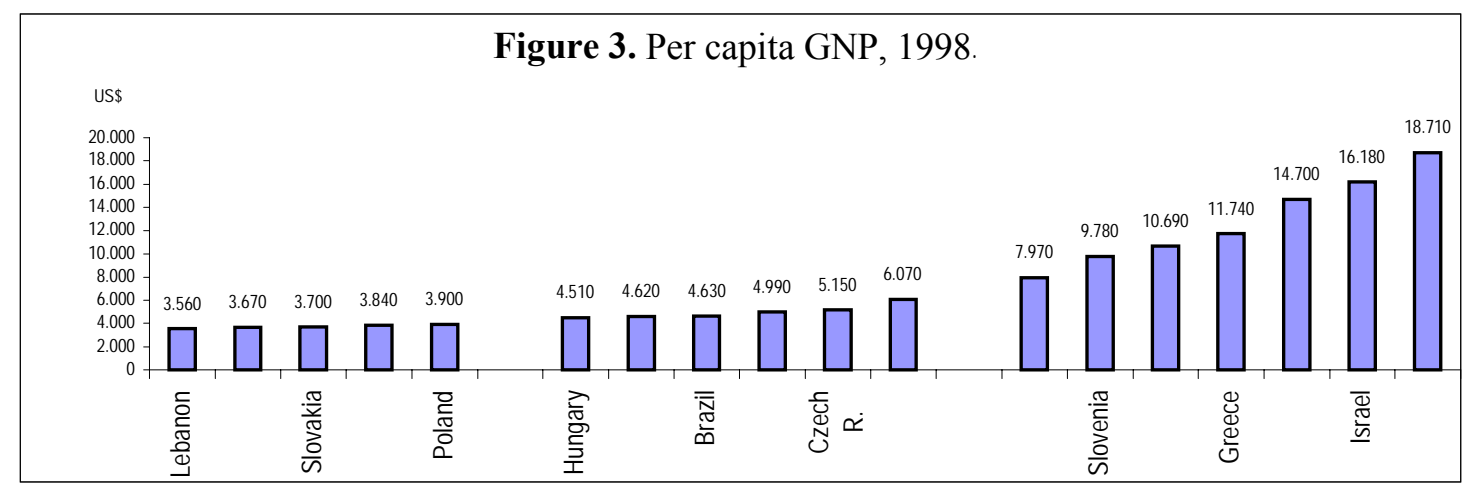

\section{Leadership commitment to economic development and social capital}

It is largely a matter of considered judgement whether political leadership in a given country is committed to economic development and how conducive is a country's social capital to the realisation of development objectives. An assessment of these factors nonetheless needs to be made because they have been identified in the literature as the key determinants of the development process (Adelman, 1990, 1999; Adelman and Morris, 1967). One approach is to ask the following questions: Is economic development in the practice of the political leadership more important than (or at least as important as) purely political objectives? Is the goal of economic development well articulated, i.e., have the potential benefits and costs of achieving this goal been explained to and are they recognised by the average voter?

Judging by the Programme of the Government outlined shortly after the electoral victory (Government of the Republic of Croatia, 2000), answers to these questions are only partly affirmative. Economic development is only in fourth place among the fundamental objectives of the government, after the strengthening of parliamentary democracy, the decentralisation of government, and the reinforcement of law and order (Chapter 2 of the Programme). In the economic part of the programme (Chapter 4), economic development is at a mere third place, and is considered in the same context as macroeconomic policies, public finances, privatisation, transportation and telecommunications, power supply, agriculture, regional development, and environmental protection.

The goal of economic development is not precisely defined. The basic objectives of economic policy are stated to be: the creation of conditions for the attainment of economic growth; increased production and employment; increased exports; restructuring of production from the points of view of technology, market orientation, business operations and ownership structure; and improving the overall competitiveness of the economy so as to attract foreign direct investment (ibid., p. 9). Export strategy, which is expected to become the prime mover behind growth and the establishment of an internationally competitive economy, is stated with somewhat greater detail. However, the goal of development of the banking and financial systems is reduced to the lowering of the price of capital in order to stimulate investment, exports, production and economic restructuring. With respect to the latter, particular attention is attached to industrial policy and the re-industrialisation of the country (ibid., p. 10). There is no statement of the potential costs and benefits of this kind of development programme.

It is obvious, then, that the government's development objectives are at present not clearly identified and to some extent are inconsistent. It is therefore hard to expect that an average citizen will recognise such objectives as something essentially new, or as something that broad segments of the economy and public administration, who are the front-runners of economic development, will be able to identify with.

Regarding social capital, a basic issue from the perspective of development policy is to identify those social and cultural characteristics of the population that can potentially enhance or impede 
economic development, and to bear these factors in mind while drawing up a development programme. A starting point for this analysis can be a rough picture of social stratification (Box 1).

Box 1. What social classes make up Croatian society?

Because of the war and profound changes in politics, the economy and society since 1991, the most recent year for which the census results are available, there are only rough estimates of the state of social stratification in Croatia. According to a recent study (Malenica, 1999), Croatian society consists of six different classes (Table 1).

\begin{tabular}{|c|c|c|}
\hline & Thousands & $\begin{array}{r}\text { Percent } \\
\text { of total }\end{array}$ \\
\hline Elite & 200 & 4.4 \\
\hline Middle class & 700 & 15.3 \\
\hline Senior professionals & 200 & 4.4 \\
\hline Small entrepreneurs & 300 & 6.6 \\
\hline Lower professionals & 200 & 4.4 \\
\hline Working class & 1,500 & 32.8 \\
\hline Peasants & 400 & 8.8 \\
\hline Retirees & 950 & 20.8 \\
\hline Unemployed & 330 & 7.2 \\
\hline Others & 520 & 11.4 \\
\hline Total & 4,570 & 100.0 \\
\hline
\end{tabular}

- The ruling political and economic elite, made up of political leadership, big capitalists and senior management. This group covered about $4.5 \%$ of the population in 1999 ;

- The middle class and its three sub-groups:

i) Senior professionals (judges, lawyers, university professors, scientists, doctors, journalists, engineers, entertainers etc.);

ii) Small entrepreneurs and tradesmen, among whom there are large differences - some enriched themselves in the last ten years, while some went under because of unstable business conditions;

iii) Lower professionals (teachers, financial sector employees, junior management and skilled technicians, lower civil servants, shopkeepers);

- The working class, made up of some 700,000 workers employed in industry. With families, the working class accounts for one-third of the population;

- Farmers and peasants, whose total increased to about 400,000 in the last ten years as some industrial workers and retirees below the age of 50 returned to the countryside. One of the consequences of this process is partial de-urbanisation: after having worked and lived in cities for 20-25 years, some retirees and unemployed returned to their native villages, leaving their city dwellings to their children;

- Retirees (950,000 people, or $21 \%$ of the population), and unemployed $(330,000$ or $7 \%$ ), many of whom are long-term unemployed;

Of the half a million people not assigned to any of these categories, a large number is believed to live and work more or less permanently abroad.

Several features of the Croatian society stand out. The proportion of retirees, who as a rule cannot lead the development process, is exceptionally high - more than $20 \%$ of the population at the end of 1999. Since, at the same time, certain basic demographic indicators are very unfavourable (see below), the question arises: does Croatia have the human resources required for economic development, or is the economic stagnation inevitable with such a population structure and labour supply? A clearer answer to this question would require a more detailed study, but one should note that among the 950,000 retirees there are probably several hundred thousand people able to work. Together with the unemployed and those non-categorised (most of whom probably work abroad), these people represent a potentially important pool of labour. In particular, under conservative assumptions, unused reserves of labour in Croatia would come to about 480,000 people, which is more than one-third of those currently employed. ${ }^{5}$

\footnotetext{
${ }^{5}$ These assumptions are: (i) one-fifth of retirees are actually capable of working; (ii) of the half a million not categorised in Table 1, a tenth would be prepared to work in Croatia if the economy took off; and (iii) the structural unemployment rate is about $7-8 \%$ of the labour force, or $1 \frac{1}{2}-2.0 \%$ of the population.
} 
A second noticeable irregularity is the relatively narrow middle class. In most contemporary societies, this is the broadest social class, encompassing about $75-85 \%$ of the population, while in Croatia it accounts for perhaps 50\% (including higher and lower professionals, small entrepreneurs and tradesmen, and working class families), or $70 \%$ if all retirees are included. ${ }^{6}$

A high degree of social fragmentation has led to the emergence of a large number of interest groups. Moreover, apart from social divisions, Croatia has historically been divided along regional lines. Sharp divisions also exist within and among different professions (e.g., journalists, economists, artists). The existence of such a large number of interest groups makes the elaboration of a development strategy an especially difficult task. Research into the sociological and cultural context of the unofficial economy and tax evasion in Croatia has shown, for example, an exceptionally high level of opportunism - the aptness of citizens, especially the young, to break the rules if the benefits from the offence are greater than the penalties anticipated - and a low degree of trust in institutions - more than $40 \%$ of people questioned in 1998 had little or no trust in the government and the legal system (Štulhofer, 1997).

The causes of this state of affairs have to be sought in numerous political and socio-economic changes that have affected the last two generations. It suffices to note five constitutions (and numerous constitutional amendments) enacted since the Second World War. The widespread lack of trust and the low level of co-operation among employees in the economy and the public sector have in particular emanated from the absence of meritocracy, which has been displaced by the system of appointments and promotions according to political aptness. Another common cause of distrust had been the practice of supplying free housing to workers through firms, based on nontransparent criteria, instead of developing a real estate market.

A special dimension of social capital that has been extensively studied in recent years is the extent of corruption. Research by the World Bank and the EBRD indicates that the quality and efficiency of regulations and government institutions in Croatia are perceived to be low, state intervention generally is judged to have a large impact on business decisions, and the extent of corruption is fairly high. ${ }^{8}$ In addition, the general investment climate - which includes indicators such as taxes, business regulations, reliability of the legal, judicial and financial system, quality of the physical infrastructure, and macroeconomic stability - is not considered favourably. ${ }^{9}$

\section{Human capital and technology}

Basic demographic indicators for Croatia give a fair amount of cause for concern (Table 2). Except for Hungary, life expectancy is up to 8 years (or 11\%) shorter in Croatia than in similar countries (average life expectancy in upper-middle income countries is 74 years). Croatia also has one of the lowest growth rates of labour force - the average for countries in the group is $2.3 \%$ per year which partly reflects negative population growth $(-0.1 \%$ on average during $1980-98)$, but also a high rate of emigration.

\footnotetext{
${ }^{6}$ These comparisons are of an illustrative character; more precise quantifications can be done only on the basis of data about incomes and the appropriate demographic and sociological studies that would, for example, make it possible to categorise retirees into standard social classes.

${ }^{7}$ On grey economy in Croatia see Bićanić and Ott (1997), Feige and Ott (1999) and Kesner-ŠKkreb (1997).

${ }^{8}$ Among the 20 countries in transition, Croatia is in the $7^{\text {th }}$ place in terms of the macro-aspects of corruption, which include the possibility of the private sector to affect statutory regulations and judicial decisions (see Hellman et al., 2000). According to the corruption perception index prepared by Transparency International, Croatia was $74^{\text {th }}$ on a list of 99 countries in 1999 , and $51^{\text {st }}$ on a list of 90 countries in 2000 . As compared with countries considered in this chapter, Croatia comes at the bottom of the list: Uruguay was not ranked, but Singapore came $6^{\text {th }}$, Hong Kong $15^{\text {th }}$, Chile $18^{\text {th }}$, Ireland $19^{\text {th }}$, Portugal $23^{\text {rd }}$, Slovenia $28^{\text {th }}$, Hungary $32^{\text {nd }}$, Czech Republic $42^{\text {nd }}$ and Poland $43^{\text {rd }}$.

${ }^{9}$ According to the investment climate index, Croatia ranks $12^{\text {th }}$ on a list of 20 economies (EBRD, 1999).
} 
Table 2. Population

\begin{tabular}{|c|c|c|c|c|c|c|c|c|c|c|}
\hline & Croatia & Slovenia & Hungary & Czech R. & Portugal & Ireland & Chile & Uruguay & $\begin{array}{l}\text { Hong } \\
\text { Kong }\end{array}$ & $\begin{array}{r}\text { Singa } \\
\text { pore }\end{array}$ \\
\hline Life expectancy at birth $1 /$ & 68 & 71 & 66 & 71 & 71 & 73 & 72 & 70 & 76 & 73 \\
\hline Labour force growth $2 /$ & -0.1 & 0.2 & -0.3 & 0.4 & 0.5 & 1.0 & 2.5 & 1.3 & 1.9 & 2.3 \\
\hline Public expenditure on health $3 /$ & 8.4 & 7.1 & 4.5 & 6.4 & 4.9 & 5.1 & 2.3 & 1.9 & 2.3 & 1.5 \\
\hline Adult illiteracy rate 4/ & 4 & 0 & 1 & $\ldots$ & 12 & $\ldots$ & 5 & 2 & 12 & 13 \\
\hline Secondary school enrolment ratio $5 /$ & 72 & 92 & 97 & 100 & 90 & 100 & 85 & 94 & 69 & 76 \\
\hline Tertiary education $5 /$ & 28 & 36 & 25 & 24 & 38 & 41 & 31 & 36 & 28 & 39 \\
\hline Public expenditure on education 6/ & 5.3 & 5.8 & 4.7 & 5.4 & 5.5 & 5.8 & 3.1 & 3.3 & 2.9 & 3.0 \\
\hline
\end{tabular}

Sources: World Bank, World Development Report 1999/2000, and World Development Indicators 2000; and the official statistics of individual countries.

1) For males born in 1997

2) Average annual growth rate for the period $1980-98$, in percent

3) Expenditure of all levels of the public sector, in percentage of GDP; data for 1997 or an earlier year.

4) For females ages 15 and above, in \%; data for 1997.

5) Percentage of children of official school age enrolled in secondary or tertiary education in 1997.

6) Expenditure of all levels of the public sector for primary, secondary and tertiary education (including subsidised private schools) in percentage of GNP; data for 1996.

Also surprising is the fact that the share of pubic sector expenditure on health care in Croatia is the highest in the group (and, apparently, in the world, with Germany a close second). While it is not possible to further explore the above data at this stage, one can hypothesise that they reflect both a relatively poor state of health of the population and large inefficiencies in the health care industry, implying the need to transfer some of the cost of health care from the public sector to the population.

Data on adult literacy are somewhat more comforting. But the rate of enrolment in schools at the secondary and tertiary level is fairly low as compared with the selected countries, in spite of a fairly high level of pubic sector expenditure on education. For example, Uruguay spends $2 \%$ less of its GDP on education but achieves enrolment ratios that are $22 \%$ higher at the secondary level and $8 \%$ higher at the tertiary level.

Unlike basic demographic indicators, the relative position of Croatia with respect to science and technology indicators is somewhat better. In terms of number of scientists and engineers, only Slovenia, Ireland and Singapore are ahead of Croatia in the group; and in terms of exports of advanced technology, Hungary, Ireland, Hong Kong and Singapore are ahead (Table 3). However, Croatian scientists and researchers are fairly unproductive in publishing papers, although the total expenditure for research and development is fairly high as compared to the other countries'.

Table 3. Science and Technology

\begin{tabular}{|c|c|c|c|c|c|c|c|c|c|c|}
\hline & Croatia & Slovenia & Hungary & Czech R. & Portugal & Ireland & Chile & Uruguay & $\begin{array}{l}\text { Hong } \\
\text { Kong }\end{array}$ & $\begin{array}{l}\text { Singa- } \\
\text { pore }\end{array}$ \\
\hline Scientists and engineers $1 /$ & 1,916 & 2,251 & 1,099 & 1,222 & 1,182 & 2,319 & 445 & 688 & $\ldots$ & 2,318 \\
\hline Scientific publications 2/ & 0.23 & 0.15 & 1.34 & 1.27 & 0.65 & 0.39 & 1.57 & $\ldots$ & $\ldots$ & 0.38 \\
\hline R\&D expenditure $3 /$ & 1.03 & 1.46 & 0.68 & 1.20 & 0.62 & 1.61 & 0.68 & $\ldots$ & $\ldots$ & 1.13 \\
\hline Advanced technology exports 4/ & 8 & 4 & 21 & 8 & 4 & 45 & 4 & 2 & 21 & 59 \\
\hline Exports of industrial products 5/ & 72 & 90 & 46 & 85 & 84 & 80 & 14 & 37 & 93 & 84 \\
\hline Agricultural productivity 6/ & 8,521 & 26,521 & 4,770 & $\ldots$ & 5,574 & $\ldots$ & 5,039 & 9,826 & $\ldots$ & 42,851 \\
\hline $\begin{array}{l}\text { Registered patents, residents } 7 / \\
\text { Non-residents }\end{array}$ & $\begin{array}{l}273 \\
439\end{array}$ & $\begin{array}{r}285 \\
27,162\end{array}$ & $\begin{array}{r}774 \\
29,331\end{array}$ & $\begin{array}{r}601 \\
29,976\end{array}$ & $\begin{array}{r}92 \\
106,595\end{array}$ & $\begin{array}{r}946 \\
82,484\end{array}$ & $\begin{array}{r}189 \\
1,771\end{array}$ & $\begin{array}{r}32 \\
370\end{array}$ & $\begin{array}{r}26 \\
2,359\end{array}$ & $\begin{array}{r}8,188 \\
29,467\end{array}$ \\
\hline Personal computers $8 /$ & 112 & 251 & 59 & 97 & 81 & 272 & 48 & 91 & 254 & 458 \\
\hline Internet hosts 9/ & 26 & 99 & 93 & 86 & 59 & 157 & 21 & 38 & 143 & 322 \\
\hline Fixed telephone lines $8 /$ & 348 & 375 & 336 & 364 & 413 & 435 & 205 & 250 & 558 & 562 \\
\hline Daily newspapers $10 /$ & 115 & 199 & 186 & 254 & 75 & 150 & 98 & 293 & 792 & 360 \\
\hline
\end{tabular}

Source: World Bank, World Development Indicators 2000 and World Development Report; and the official statistics of the individual countries.

1) Employed in scientific research per million inhabitants; data for 1998 or earlier.

2) Papers from the area of scientific or technical sciences or medicine published in scientific journals per employee in scientific research institutes, data for 1995 or earlier.

3) Current and capital expenditure for fundamental and applied science and the development of new products and processes in percent of GDP; data for 1997 or earlier.

4) Share of exported goods with high scientific research content (aircraft equipment, computers, pharmaceutical goods, scientific instruments, electrical machinery etc.) in the total exports of industrial products, in percent; data for 1998.

5) In percent of total exports, data for 1998.

6) Value added of agricultural production per person employed on the land, average for 1996-98; values expressed in constant dollar prices of 1995.

7) Number of patents registered in the country by residents and non-residents; data for 1997.

8) Per thousand inhabitants, data for July 1999.

10) Number of copies of daily papers distributed per thousand inhabitants, data for 1997. 
To some extent, the share of industrial products in total exports is satisfactory, as are productivity in agriculture (although Croatia is considerably behind Slovenia), number of personal computers, and the fixed telephone network. However, in terms of the internet connections and newspaper readership, Croatia is near the bottom of the list. The situation with respect to registered patents of non-residents is nearly catastrophic, which indicates significant problems in attracting foreign investors with advanced technologies. To some extent, there is consolation in the fact that the attitude towards foreign investors and the acceptance of new technology can be changed rapidly with a good development policy, whereas it takes much longer to increase the pool of the domestic $R \& D$ personnel. On the other hand, these statistics provide little information about the quality of the R\&D staff.

One exceptionally important aspect of human capital, though by its nature difficult to assess, is the organisational and managerial capacities of people in top positions in the economy and the public administration. From media reports it can be concluded that there is a widespread perception about the poor organisation and lack of professionalism and corporate governance in Croatia. Although in this area there has not recently been any systematic research to bear out such viewpoints (one exception is Institute of Public Finance, 1998) it is a fact that this problem has a long history in the country. ${ }^{10}$

\section{Economic policy}

The most commonly used and in practice the most relevant aggregate measures of the "maturity" of the economic policy of developing countries are the credit rating of long-term government bonds, and the spread between a country's sovereign bonds and US Treasury bonds. Although objections can be made to these criteria (see e.g., Kuhner, 1998), credit ratings and interest rate spreads are essential economic credentials in international capital markets. Investors from industrial countries cannot ignore the credit ratings because of regulations about investment risk agreed within the framework of the BIS. Governments of the developing countries cannot ignore the credit ratings and bond spreads because these indicators determine the costs of financing budgetary and external current account deficits. Bonds issued by the Republic of Croatia are currently rated between the speculative and investment grades (Table 4). As compared with the bonds issued by other middle-income countries, Croatian bonds are not rated the lowest.

\footnotetext{
${ }^{10}$ Consider the following observation from the early eighties: "In leading business functions there are many inadequate cadres, who are not up to the job, and slow down and ruin development and drive away capable and particularly younger cadres. They are not capable of or ready for business and developmental dynamics and innovation, for initiative and risks. They do not understand development, and are afraid of it, as a threat to themselves, and thwart it, and concern themselves more with politics and cliques.... A more permanent solution is possible only if our economy and society, from the whole to all the parts of it, are brought in order from the perspectives of organisation, management and the provision and analysis of information (Gorupić, 1982, p. 5 and p. 7).
} 
Table 4. Crediting rating of long-term foreign currency bonds, September 2000

\begin{tabular}{|c|c|c|}
\hline $\begin{array}{l}\text { Rating } \\
\text { agency }\end{array}$ & $\begin{array}{l}\text { Croatian } \\
\text { rating }\end{array}$ & Credit ratings definitions \\
\hline $\begin{array}{l}\text { Rating } \\
\text { system: } \\
\text { Aaa, Aa, A, } \\
\text { Baa, Ba, B } \\
\text { Caa, Ca, C }\end{array}$ & Baa3 & $\begin{array}{l}\text { Medium-grade obligations, neither highly } \\
\text { protected nor poorly secured. Interest } \\
\text { payments and principal security appear } \\
\text { adequate for the present but certain protective } \\
\text { elements may be lacking or may be } \\
\text { characteristically unreliable over any great } \\
\text { length of time. Such bonds lack outstanding } \\
\text { investment characteristics and in fact have } \\
\text { speculative characteristics as well. Numerical } \\
\text { modifier "3" indicates a ranking in the lower } \\
\text { end of that generic rating category. }\end{array}$ \\
\hline
\end{tabular}

Standard
and Poor's

Rating system

AAA, AA, A

$\mathrm{BBB}, \mathrm{BB}, \mathrm{B}$

$\mathrm{CCC}, \mathrm{CC}$

$\mathrm{R}, \mathrm{SD}, \mathrm{D}$

An obligor with an adequate capacity to meet

its financial commitments. However, adverse economic conditions or changing circumstances are more likely to lead to a weakened capacity of the obligor to meet its financial commitments. The minus means that the debtor is at the bottom of this rank.

Obligors rated lower than BBB are regarded as having significant speculative characteristics.

A minus sign indicates a lower relative standing within the rating category.

Similar ratings

Higher rank: Singapore

(Aa1); Hong Kong and

Slovenia (A3); Hungary,

Czech R., Poland and Chile

(Baa1); Korea (Baa1).

Same rank: Malaysia,

Mexico, Thailand,

Uruguay.

Lower rank: Slovakia,

China and the Philippines

(Ba1); Argentina, Turkey and Lebanon (B1).

Higher rank: Singapore

(AAA); Ireland (AA+);

Portugal (AA); Slovenia

and Hong Kong (A); Czech

R. and Chile (A-); Hungary

and Poland $(\mathrm{BBB}+)$.

Similar rank: Egypt,

South Africa, Thailand,

Uruguay.

Lower rank: Slovakia and

Mexico (BB+); Argentina

and India (BB).

\begin{tabular}{llll}
\hline Fitch IBCA & BB+ & $\begin{array}{l}\text { Speculative rating, indicates that there is a Higher rank: Ireland } \\
\text { possibility of credit risk developing, (AAA); Singapore (AA+); }\end{array}$ \\
Rating & particularly as the result of adverse economic Portugal (AA); Hong Kong \\
system: & change over time; however, business or (A+); Slovenia (A); Chile \\
AAA, AA, A & financial alternatives may be available to (A-); Poland (BBB+); \\
BBB, BB, B & allow financial commitments to be paid. Uruguay (BBB-). \\
CCC, CC, C & Securities rated in this category are not Same rank: Slovakia, \\
DDD, DD, D & investment grade. The plus sign denotes a South Africa, Mexico. \\
& higher relative standing within this rating Lower rank: Argentina \\
& category. & (BB).
\end{tabular}

Sources: www.moodys.com, www.standardandpoors.com, www.fitchibca.com

In particular, Croatia's credit rating is higher than that of most Latin American countries, although their banking and financial systems are generally far more developed. This can be explained by the fact that Croatia received its first credit ratings after establishing macroeconomic stability in the mid-1990s, while the ratings of the Latin American countries have been negatively affected by the debt defaults of the 1980s and a long history of macroeconomic instability. When Mexico graduated from the Moody's speculative grade to the medium rating (same as Croatia's) in spring of 2000, it was after many years of substantial fiscal, banking and monetary reforms. Clearly, any upset to Croatia's macroeconomic stability would cost the country dearly in the international capital markets and would probably have long-term consequences for its credit rating.

Since credit ratings change fairly infrequently, assessments of the state of economic policy in the short term can be made more accurately on the basis of the spread between a given sovereign bond and the US Treasury bond of similar characteristics. Since government bonds are traded daily on the secondary market, the bond spreads reflect fairly accurately all essential changes in short-term economic policy and in the economic and political situation in general. Thus, for example, interest on five-year euro-denominated Croatian bonds issued in mid-February 1997 oscillated between 66 and 932 basis points, with an average of almost 300 basis points above the corresponding US bonds (Figure 4). Of particular interest is that, after a sharp decline at the beginning of 2000 (to 
150-200 basis points from more than 500 points in 1999), the spread has been constantly on the rise from mid-April, reaching 250 basis points at the end of October. This trend reflects investor nervousness about the constant questioning of the exchange rate, monetary and fiscal policies (Fitch IBCA, 2000). Thus, when some Croatian economists questioned the need for stable macroeconomic policies in mid-March 2001, the spreads jumped almost immediately by some 30 basis points, falling off a week later following the announcement of a stand-by arrangement with the IMF. The size of this impact should not be underestimated. With external debt of $\$ 10$ billion, an increase in the bond spread of one percentage point raises the annual debt servicing costs by $\$ 100$ million, which is equivalent to $20 \%$ of the annual budget for education or $50 \%$ of the annual budget for science and technology.

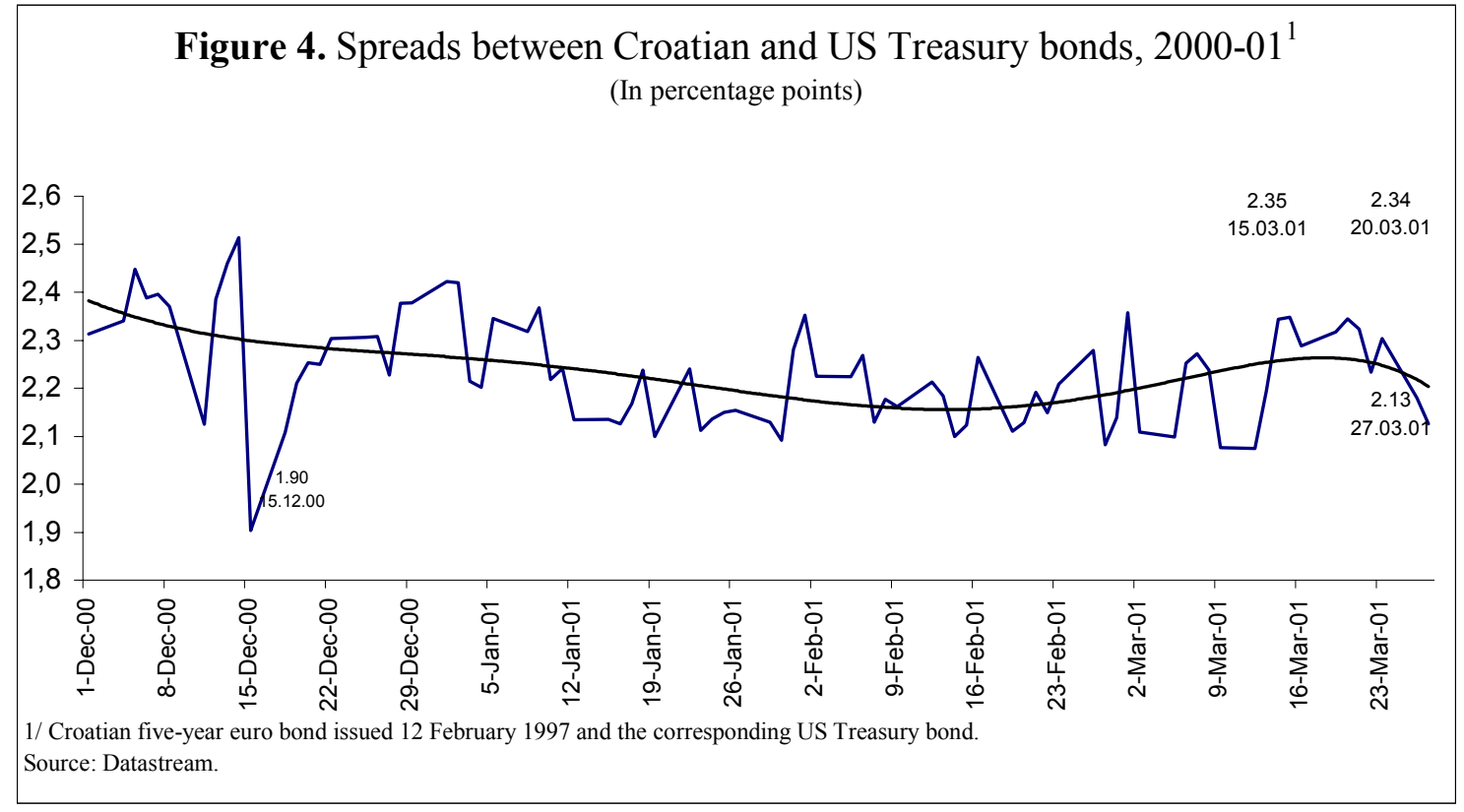

Compared with the other emerging market economies, Croatian bond spreads are higher than those of the Central European and most Asian countries, but lower than those of the Latin American countries (Figure 5). In other words, the costs of financing on the international capital market are lower for Croatia than for countries with a long history of macroeconomic instability, even though the macroeconomic indicators in these countries are at the moment better than, or just as good as, those in Croatia.

\section{Institutions, productive capital and physical infrastructure}

According to the selected indicators of quality of physical infrastructure - efficiency of energy use and quality of the road network - Croatia does not lag behind similar economies (Table 5). The existing physical infrastructure is for the moment a good basis for future development. On the other hand, selected investment and institutional indicators are very unpropitious. Croatia has the lowest rate of investment among the selected economies (22\% of GDP as against $30-35 \%$ in the rapidly developing countries), the lowest private sector share in total investment $(60 \%$ as against $88 \%$ in upper-middle income countries), and the highest tax burden (current revenue of the central government budget accounts for $43 \%$ of GDP as against the average of $38 \%$ for the OECD countries and $18 \%$ for developing countries (Tanzi and Zee, 2000)). 
Table 5. Infrastructure, investment and institutions

\begin{tabular}{|c|c|c|c|c|c|c|c|c|c|c|}
\hline & Croatia & Slovenia & Hungary & Czech R. & Portugal & Ireland & Chile & Uruguay & $\begin{array}{l}\text { Hong } \\
\text { Kong }\end{array}$ & $\begin{array}{r}\text { Singa- } \\
\text { pore }\end{array}$ \\
\hline GDP per unit of energy use $1 /$ & 4.0 & 4.4 & 4.0 & 3.3 & 7.1 & 6.0 & 5.7 & 9.7 & 10.6 & 2.9 \\
\hline Paved roads $2 /$ & 82 & 83 & 43 & 100 & $\ldots$ & 94 & 14 & 90 & 100 & 97 \\
\hline Investment rate $3 /$ & 21.7 & 23.4 & 27.0 & 30.0 & 26.4 & 20.0 & 26.6 & 13.6 & 31.3 & 35.9 \\
\hline Private investment 4/ & 60 & 90 & $\cdots$ & 91 & $\cdots$ & 90 & 81 & 72 & 84 & 80 \\
\hline Foreign direct investment 5/ & 4.0 & 0.8 & 4.0 & 4.5 & 1.7 & 3.6 & 5.9 & 0.8 & $\ldots$ & 8.6 \\
\hline Private sector bank loans 6 / & 41 & 33 & 48 & 60 & 103 & 94 & 62 & 35 & 169 & 110 \\
\hline Interest rate spread $7 /$ & 11.1 & 5.5 & 3.2 & 4.7 & 3.9 & 5.8 & 5.3 & 42.8 & 2.4 & 2.8 \\
\hline Current tax revenue $8 /$ & 43 & 40 & 33 & 33 & 31 & 32 & 19 & 28 & 13 & 16 \\
\hline
\end{tabular}

Sources: World Bank, World Bank Development Indicators, 2000 and World Development Report 1999/2000; IMF; and the official statistics of the individual

1) GDP (at purchasing power parity, in constant 1995 US dollar prices) produced per unit of energy spent for commercial purposes (kg oil equivalent); data

for 1997. Higher figures represent more efficient energy use.

2) Percentage of paved roads, data for 1997.

3) Percentage share of gross domestic investment in GDP, 1994-98 average.

4) Percentage share of private sector investment in total investment; data for 1997.

5) Percentage share of gross foreign direct investment in GDP; data for 1998.

6) Bank loans to the private sector as a percentage of GDP; data for 1998

7) Interest rate spread between short-term loans and deposits, in percentage points; data for 1998

8) Current tax revenue of the central government budget, in percent of GDP; data for 1997.

A low rate of investment over an extended period of time, with a small private sector share and a high tax burden, suggest that Croatia's productive capital is obsolescent and needs to be renewed. ${ }^{11}$ Data about the structure of investment - construction works account for $50-60 \%$ of the total value of investment and equipment for only $40 \%$ - further corroborate this conjecture. For comparison, US investment in equipment in the last five years amounted on average to $73 \%$ of total private sector investment. Even more disturbing are the data on financial sector development. Private sector loans in Croatia accounted for only about $40 \%$ of GDP in 1998, as compared with $100 \%$ or higher in industrial countries. Moreover, the spread between lending and deposit rates 2-3 times higher than in the advanced emerging market economies.

${ }^{11}$ The share of foreign direct investment is relatively high, but in most cases this reflects the initial purchase of equity in public corporations rather than greenfield investments. 
Slika 5

Bond spreads *

January-September 2000
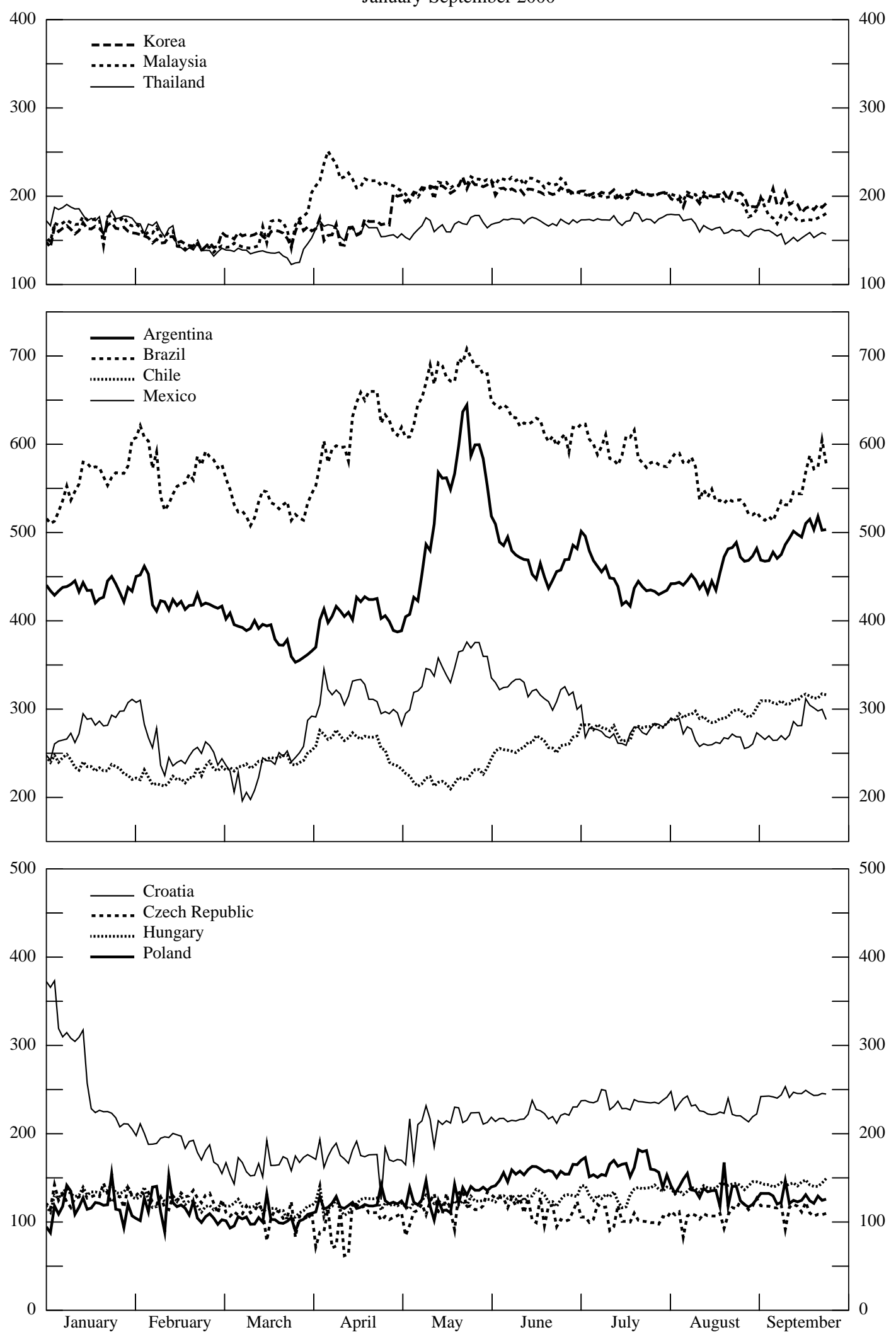

* Over benchmark US Treasury bonds; in basis points. 
These data clearly indicate that greater attention needs to be devoted to the development of financial markets and institutions (including the tax system) than to the upgrading of the road and power systems. Without sound banks, a stable and efficient taxation system, and a liquid market for securities, it is hard to foster the entrepreneurship, increase productive investment and, ultimately, reduce the role of the state in the economy.

Finally, the natural beauties and historical and cultural heritage of Croatia are potentially valuable development resources. In terms of foreign tourist visits, Croatia ranked $18^{\text {th }}$ in the world in 1990, and $33^{\text {rd }}$ in 1998 (World Tourism Organisation, 2000). In terms of earnings per tourist, Croatia ranked $17^{\text {th }}$ in the world in 1998 , and with $\$ 665$ of revenue per foreign visitor it was ahead of tourism powerhouses such as Austria, Spain, Greece and France (Figure 6). It would thus appear that the economic potential of Croatian tourism is indeed significant. Nonetheless, it would be incorrect to conclude that the strategy of long-term development should be based on tourism, because the economic potential of tourism cannot be exploited without general development (Sinclair, 1998).

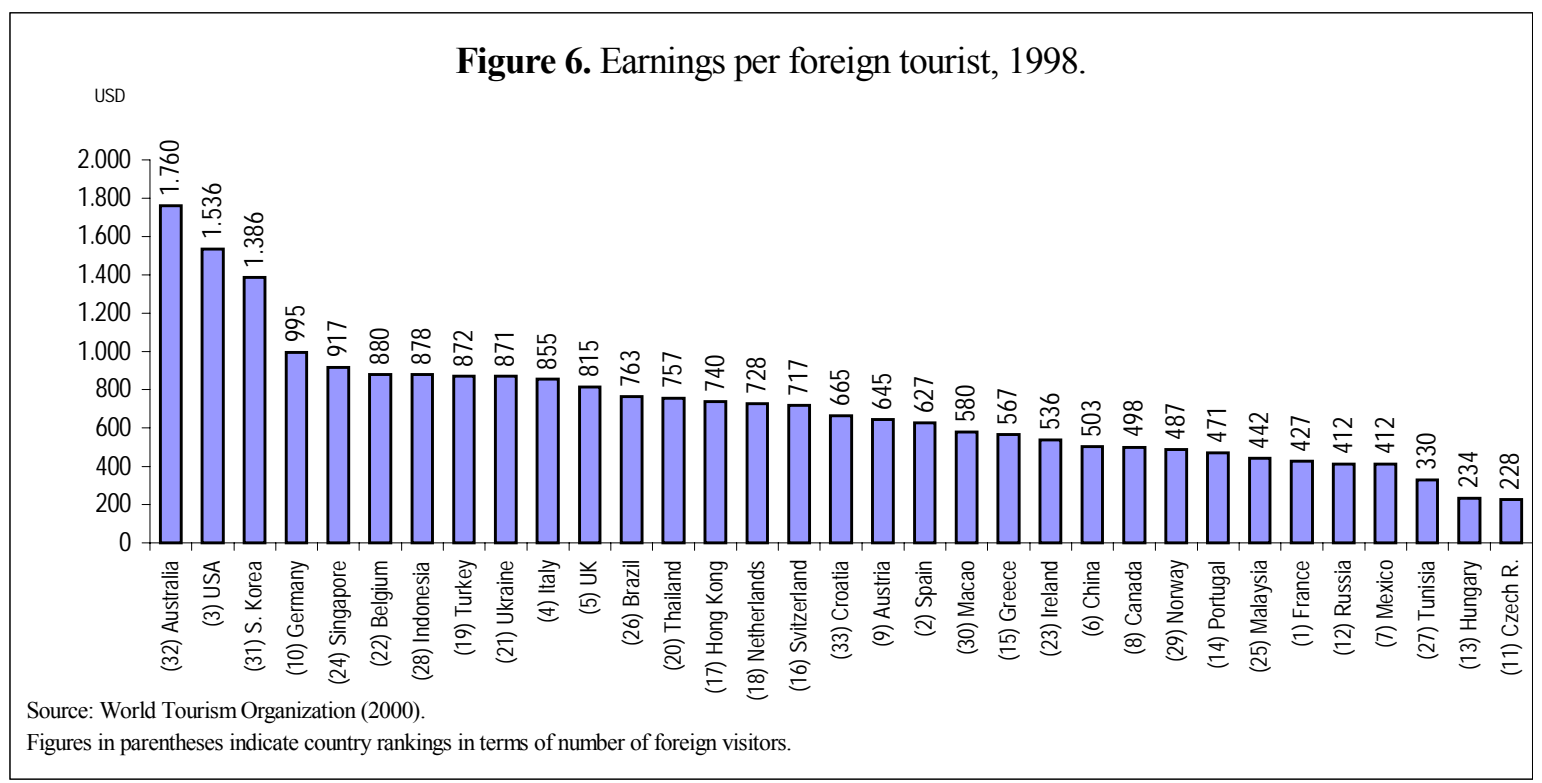

In summary, the balance sheet of Croatia's development potentials is not brilliant. Resources that could be used for rapid development include a technically well-educated labour force, a relatively developed industrial tradition, macroeconomic stability, a sound physical infrastructure, and natural resources suitable for the development of tourism. Key weaknesses are: unclear development priorities, a large number of interest groups, lack of managerial and organisational skills, unfavourable demographic trends, obsolescent productive capacities, low penetration rate of information technology, lack of entrepreneurial culture, and underdeveloped financial markets and institutional infrastructure, in particular the legal system and the judiciary. 


\section{WHAT TO DO, AND HOW TO DO IT?}

\section{Basic principles for Croatia's development strategy}

From the perspective of development theory and policy, Croatia finds itself in a historically propitious situation because it can draw on a wealth of experience from other countries and does not have to experiment with the application of a development model that has not yet been tested. Croatia has also enough bad experience from its own history to be exceptionally cautious about any idiosyncratic model of development. ${ }^{12}$ Thus, in answering the questions: "What to do?" and "How to do it?" our aim is to clearly identify and justify the main principles that should be adhered to in drawing up a development strategy, rather than to compile a whole list of development problems and a catalogue of possible solutions. In drawing up such development principles, we bear in mind the current state of knowledge about economic development, the potentials and weaknesses of the Croatian economy, and indications of coming trends in the world economy.

\section{Define a clear development objective}

An integral part of the development strategy is to define a clear and realistic objective for economic development. In the age of global communications and after the failures of development that two post-war generations in Croatia have had to come to terms with, it is an illusion to think that any government could capture the attention of the public with vague and ill-defined objectives like "improving the quality of life" or "achieving growth and economic development with accelerated employment". In a market economy, people every day compare their incomes with the cost of living. Thus it is entirely logical for economic progress at the level of the economy to be measured by real per capita income. One clearly defined and identifiable development objective would be the doubling of the per capita income in the next 10-15 years. The next chapter shows that this objective is ambitious but realistically attainable. Croatia can, in the next 10-15 years, achieve a per capita income of about $\$ 10,000$ provided that it sustains an average annual growth of $5-6 \%$, which is entirely within the scope of growth experiences of either Croatia or similar developing countries.

In this context, it is worth mentioning that Croatia's membership in the European Union is another desirable development objective, not only economically but also politically as well as from a historical and cultural perspectives. But for some time, the terms of Croatia's membership in the EU will not be clearly drawn, and even when they are made more precise, the accession dynamics will remain uncertain and dependent upon many factors beyond the control of the Croatian government, economy and society, such as political events in Southeast Europe, EU experience with new members, and the overall political and economic situation in the EU. In such circumstances, it would be wiser to found a development strategy on an objective such as doubling of the per capita income. This goal is entirely compatible with Croatia's membership in the EU, but leaves the authorities some additional flexibility in development policy.

Furthermore, it should be noted that membership in the EU does not guarantee that the economy and employment will grow. Although a member of the EC since 1973, Ireland was stagnating until the radical turnabout in fiscal and developmental policies in the early 1990s. Joining the EU would not by itself put an end to the problems of high unemployment, low growth, corruption and a bleak outlook in Croatia. Unemployment could even rise temporarily, and the Croatian government would still have to run its own economic and development policies.

12 In the post-Second World War period, Croatia has experimented without any lasting success with five different economic models: central planning (1945-50), planning of global proportions with elements of a market economy (1951-64), market liberalism (1965-72), self-managed market economy (1973-89) and finally state capitalism with elements of a laissez-faire economy (1990-99). 


\section{Ensure equal access to development opportunities}

The conclusion that transparency and equality of access to development opportunities rather than industrial policy should become the foundation of Croatia's new development orientation follows from three key observations.

With the establishment of the World Trade Organisation (WTO), the rules of the game in international trade have changed in an essential way. Most incentives that countries such as Japan, South Korea and Taiwan provided 30 years ago to encourage domestic export-oriented industries and limit competition in import-substituting industries (e.g., rules on minimum domestic content, tax breaks for selected industries) violate the WTO rules. But even if the use of such measures were permitted, Croatia would not be in a position to implement them in a cost effective way because it does not posses the superior administrative and institutional capacity necessary to implement targeted measures of industrial support. It is highly doubtful, for example, that Croatia's poorly-trained and underpaid civil servants would be capable of organising and impartially administering contests for export incentives on the basis of transparent criteria of efficiency, as was standard practice in Japan, Korea and Taiwan in the past.

The experience of transition economies in Central and Eastern Europe provides another argument against reliance on industrial policy. The main source of growth in Poland, the Czech Republic and Hungary over the past decade was the newly established private sector, mostly small- and medium-sized firms, not the big industrial enterprises inherited from socialism. Such firms are much quicker in spotting the opportunities for profitable investment and much more flexible in organising production and hiring labour. To unleash the entrepreneurial drive necessary for the growth of such firms, it is necessary to deregulate the goods and services markets and in particular the labour market. Large industrial firms also have a role to play in future economic development, but only if they are thoroughly restructured. The experience of the advanced transition economies indicates that the best results are achieved when, under pressure from foreign and domestic competition, large industrial firms are linked up with foreign strategic partners.

The third argument against industrial policy is that, in the presence of a large number of interest groups, every attempt to target specific industries or regions for development would lead to a deepening of social distrust and wasteful quarrels about the distribution of incentive resources. Instead of re-invigorating the economy, industrial policy would poison the already poor relations in the Croatian economy, politics and society. ${ }^{13}$

\section{Adjust to globalisation and the new economy}

One of the basic development principles highlighted in this paper is that the Croatian economy has to adjust to global economic and financial trends and accept the economic implications of the new technology. The changes that have occurred over the past decade in the mode of production and the provision of services, in the financing of investment, and in the structure of labour markets are so deep that, even in countries like Germany and Japan, firms and institutions that fail to adjust risk being marginalised.

It is of particular importance for Croatia's future development to note that the technological revolution has led to fundamental changes in the notion of comparative advantage. The new information and communications technology has significantly expanded the scope for geographical specialisation in the production of goods and services, so that today not even the most highly developed economies produce a full range of products "from pins to airplanes". Rather, the bulk of international trade for the past 20 years or so has consisted of intra-industry trade and trade in differentiated products and services. As a consequence, there is almost no industrial product or commercial service that can be provided exclusively, or evenly mainly, from domestic components. In such circumstances, the concept of comparative advantage can no longer be applied to whole industries or even to individual products, but only perhaps to components of products (e.g., the tungsten filaments in bulbs, liquid crystal displays) or individual parts of the

\footnotetext{
13 A comparative study of industrial countries' experience concluded unequivocally that industrial policy would not give the expected results in Croatia (Kesner-ŠSkreb, 1995).
} 
production process (e.g., assembling the bulbs, selling of books via the internet). For this reason, development policy that is based on encouraging whole industries - like the often-mentioned "national industries" of Croatia such as shipbuilding, machine building, shipping and tourism - has literally no future. Domestic manufacturing and service industries in all sectors simply have to link up with successful foreign firms, adjust to the demands of purchasers, and the whims and vagaries of consumers if they want to maintain or increase production and employment. The example of Slovenia, which very rapidly stepped up its exports of relatively low-tech industrial products, shows that such adjustment can be made without large capital investment, but not without specialisation and good organisation, assisted by the application of the standard information technology.

Comparative advantage in a traditional sense today exist only for a small number of products and services with specific geographic characteristics or authentic features. These are, for example, certain food and agricultural products, certain segments of tourism, art products, fashions, cultural activities and the like. In order to encourage the better supply of such products, it is necessary to invest much more in quality and marketing. This will be helped most by entrepreneurial innovation, deregulation, and the strengthening of domestic competition, above all by the removal of barriers (most frequently at the local level) to starting up new firms and to the free distribution of products and services. But it should be clear that the development of a whole economy cannot be based only on such narrow segments of production.

Globalisation and the new communications technology have also led to much greater homogeneity of consumer preferences. With global media and communications and a much greater mobility, domestic consumers cannot be treated as less selective or as having different tastes from foreign consumers. Since these changes in the structure of consumer demand are of a permanent character - in Croatia they have been present ever since shopping trips to Trieste in the seventies - there have to be appropriate changes in the structure of supply if domestic industry wants to survive. In particular, the differences between production for export and production for the home market have to vanish. Greater competition resulting from joining the WTO will have an even greater influence on the disappearance of the dichotomy between export- and domestic-market products, and will impose efficient production of quality goods and services - irrespective of where they are finally consumed - as the imperative for business survival.

An application of these principles can be illustrated with the example of tourism. Tourism services can be divided into homogenous components (transportation, accommodation, hotel services, tourist information, some types of food and leisure activities) and the experience components natural and cultural beauties, cultural experiences, local wining and dining, souvenirs, authentic forms of entertainment (folk music, local music) and the like. In the case of the homogenous tourist services, the standards that foreign and domestic consumers expect are more or less the same world-wide and have to be met impeccably; here, linking up with successful foreign firms (hotel chains, for example) is unavoidable. Regarding experiental components of tourism, there is much greater scope for innovation and creativity rather than copying of foreign examples. And for tourists really to be offered a unique experience, a synergy has to be created between established cultural and tourist organisations, private entrepreneurs, the public sector and the local population. It follows that organisational and managerial skills, market research and active promotion are essential to develop tourism. Since these activities require co-ordination among many suppliers, intensive data and information analysis, and establishing a permanent presence in domestic and foreign media, the application of information technology again emerges as a sine qua non for the development.

\section{Reform the labour market}

Lower unemployment should clearly become a key priority of the development strategy. From a policy perspective, it is easier to tackle the problem of raising the employment, partly because unemployment is one of the macroeconomic variables most difficult to measure. In particular, the "equilibrium" level of unemployment, the so-called non-accelerating-inflation rate of unemployment, is difficult to estimate even with the help of first-rate statistics. In Croatia, however, even elementary statistics are unreliable: the rate of unemployment was officially estimated at about $21 \%$ in late 2000 , while according to ILO methodology the estimated rate was about $12 \%$. In contrast, employment can be measured much more precisely and with a shorter time 
lag. More importantly, empirical research and economic policy have proved much more effective in analysing factors that influence the growth of employment.

What is the current state of the labour market in Croatia? There is little doubt that the labour market in Croatia is extremely rigid: it is mainly ruled by collective contracts; the fixed costs of hiring and firing are very high; and non-wage labour costs (mainly social security contributions, but also such arcane items as subsidies for public transport, hot meals, and annual leave) are on the order of $60-80 \%$ of net wages. The risk of hiring is thus extremely high for employers, and very few new jobs get created as a result. Employers are instead encouraged to employ staff under temporary contracts or not to report some of their workers. These hiring practices negatively affect job prospects of the young, women, and well-educated first-time job seekers. The employed workers who are dissatisfied with their current job are also affected because they do not wish to look for new jobs - in which they could well be more productive - out of fear of unemployment. At the same time, because employees stay in the same jobs for years, the capacity of the economy to absorb new know-how and technology is limited.

Another consequence of the labour market rigidity is the tendency to substitute capital for labour. As the price of labour relative to capital is high, Croatian entrepreneurs are encouraged to utilise production techniques that are capital-intensive. Such allocation of production factors is not optimal at the current level of development, when labour is still a relatively abundant factor compared with capital, and when labour-intensive technologies should predominate in a steady state equilibrium.

Labour market rigidity also has important consequences for the mix of macroeconomic policies. Because of the constant pressure of unemployment on the state budget, there is the need to run a relatively restrictive monetary policy, which acts as an additional constraint on the growth of production and employment.

At the microeconomic level, collective bargaining can lead to major inefficiencies in the allocation of labour. Successful firms like Pliva compete today globally not only in the goods and services markets, but also in the factor markets. This relates primarily to professionals and managers, who are at times in short supply even in the most developed countries - the United States have for years been employing computer specialists from developing countries like India, Russia and Croatia. The shortage of such talent in transition economies can be exacerbated by the rigid labour market based on collective bargaining. In particular, the logic of shareholder value requires that the salaries of professionals and managers be determined on the basis of individual performance, not the collective contract. Such performance based compensation has been one of the major factors responsible for the slow growth of unit labour costs and the rapid growth of productivity and employment in the US, Ireland, the UK, the Netherlands and some Scandinavian countries in the 1990s. In contrast, in economies where the wage setting has been an outcome of collective bargaining (Germany, Croatia), the wage increases have generally exhausted the growth in labour productivity, thus depressing the profits and discouraging investment and the opening of new jobs.

To break away from this bad but stable equilibrium, the fixed and variable costs of labour particularly the high social security contributions - have to be reduced. This implies that reforms of the retirement and healthcare systems are essential components of successful labour market reform. Second, a more flexible labour legislation aimed at reducing the excessive employment protection needs to be put in place. Job protections almost always favour the employed, or insiders, at the expense of the unemployed, or the outsiders. This problem is present in all economies with rigid labour legislation, and has been analysed extensively in the case of Germany, whose labour legislation and the practice of tripartite collective bargaining has been taken over to a great extent in Croatia. Third, the high tax burden on enterprises needs to be reduced. Empirical research indicates that a reduction in overall taxes by $1 \%$ of GDP increases the growth rate of employment in the OECD countries by $0.05 \%$ per year (Garibaldi and Mauro, 1999). If this relation were to hold in Croatia, a reduction in total company taxes by $5 \%$ (from $20 \%$ to $19 \%$ of GDP) would help create about 6,500 jobs each year after the tax cut.

This line of reasoning has seldom been followed in professional and public debates about the problem of unemployment in Croatia. The dominant view has been that the cost of labour in Croatia is high because of an overvalued exchange rate. This view is, however, false. As discussed above, the problem of relatively high labour costs in Croatia is the problem of high non-wage 
labour costs, not the problem of high net wages. Labour is more expensive in Croatia than in Hungary, the Czech Republic or Poland because domestic and foreign employers have to pay much higher social security contributions and face higher costs of hiring and firing, not because the net wage of Croatian workers relative to their productivity is higher. ${ }^{14}$ An adjustment of the exchange rate would not change the ratio of the non-wage labour cost to wages, which is critical for hiring decisions, nor would it diminish the risk of hiring for employers. For domestic employers - who rely entirely on the domestic labour force because they are not capable of organising production abroad on the basis of comparative costs - devaluation would not change the cost of labour at all.

On the other hand, if pension reforms are implemented so that the costs of financing the disproportionately large number of retirees is not borne only by the employed; if the costs of health insurance are partly shifted from the companies to the general population; and if the costs of hiring and firing are reduced, the non-wage labour costs would be considerably reduced. This would lead to a reduction in the price of labour without any cut in net salaries, encouraging job creation. Precisely such trends have been observed in the economies that have carried out fundamental reforms of the social security system and labour markets over the past decades Ireland, Hungary, the UK, Canada and the US.

Finally, one should comment on another frequent proposal for reducing the unemployment reducing the interest rate in order to create easier financing conditions for domestic businesses. This proposal is irresponsible both politically and economically. Bank loans are certainly not the "right" of businesses, but the risky investment of the private savings of citizens. Moreover, with price of labour already high relative to the price of capital, a reduction in interest rates would further encourage employers to substitute capital intensive technologies for labour. This would only tie up the Croatian economy in its current bad equilibrium of low growth and high unemployment.

\section{Develop the financial markets}

Well functioning financial markets contribute to economic development in several ways:

- By raising the efficiency of financial intermediation between the agents who save and those who invest and thus increase the GDP;

- By encouraging the growth of overall domestic savings, since the availability of financial instruments makes it possible to channel the savings into activities that increase investment and employment;

- By allowing policy makers to rely on indirect instruments of macroeconomic policy such as open market operations, which are more efficient than the direct instruments such as changes in the mandatory reserves of banks;

- By encouraging the development of institutions necessary for the efficient functioning of the market economy: orderly property rights, effective bankruptcy procedures, a rigorous system of financial supervision etc.;

- Financial markets facilitate the implementation of the reforms of the health care and retirement systems, which are essential for a lasting fiscal consolidation;

- Developed financial make can also strengthen the constituency for domestic currency.

The following are some concrete proposals for the development of the financial markets.

\footnotetext{
14 There has been no systematic comparative analysis of the relationship between net wages and labour productivity in transition economies, but on the basis of employer surveys and media reports it cannot be concluded that the productivity of workers in Croatia is too low compared with their net wages.
} 


\section{Restructuring the banks and corporations}

The total costs of restructuring Croatian banks were estimated at about $25 \%$ of GDP in the past decade (Škreb, 2000), which is equivalent to four and a half years of nominal GDP growth at an annual rate of 5\%. Most of these costs were inherited from socialism or arose when in 1991-92 the former National Bank of Yugoslavia appropriated the foreign exchange reserves of the former federal state, as a result of which the Croatian National Bank was forced to convert some $\$ 3.2$ billion of foreign currency savings of the population into a public debt. Since the corporations largely financed their activities with bank loans, the costs of bank restructuring include a large part of the costs of bailing out the corporations. Other costs of corporate restructuring include the budgetary resources used to bail out companies, write off uncollected supplier loans, and write off share values of the capital of the companies. Taking these additional costs into account, it would probably not be exaggerated to put the total cost of restructuring the banks and the corporations at about $35 \%$ of GDP, which is equivalent to 6 years of economic growth at an annual rate of $5 \%$.

To stop further accumulation of these costs, bank and corporate restructuring should be completed as soon as possible. In 1999-2000, several large Croatian banks were sold to foreign strategic investors, which proved to be the most successful method of restructuring state-owned banks in transition economies and the emerging markets in Asia and Latin America. Fears that banks bought by foreign strategic partners would drain domestic savings abroad and ignore certain sectors of the economy that are potentially important for economic development (small- and medium-sized enterprises, agriculture) have largely proved to be unjustified. Empirical studies have found that the foreign bank entry improves the functioning of domestic banking markets, both by increasing the degree of competition and by introducing a variety of new financial products and better risk management techniques (see Claessens, 1999; and Hawkins and Mihaljek, 2001). To enhance their competitive position, foreign banks quickly start offering services to households and other neglected sectors of the economy. Foreign banks also bring state-of-the art technology and training for domestic bankers. Moreover they are familiar with sophisticated financial instruments and techniques, and have faster and cheaper access to international capital markets and liquid funds. Their presence may also encourage other foreign firms to invest in the domestic economy (Goldberg et al., 2000).

\section{Solving the problem of payment arrears}

During 1998-99, Croatian enterprises and the public sector ran up large payment arrears vis-à-vis their suppliers, the banks, and the state budget; in addition, enterprises accumulated large wage arrears and the central government large pension arrears. Other transition economies faced similar problems in the past: in Poland and the Czech Republic, inter-enterprise arrears peaked at about $20 \%$ of GDP, and in Romania at about $50 \%$ of GDP. This problem has been shown to be primarily a consequence of poor legal and financial discipline, and not a sign of macroeconomic disturbances - in market economies, supplier loans often amount to about $20 \%$ of GDP without posing any threat to the payment system or macroeconomic stability (Begg and Portes, 1993; Rostowski, 1994; Begg, 1996).

The basic solution to the problem of payment arrears is therefore to insist that financial contracts be honoured, which can be achieved through reciprocal settling of debts, collection of interest on unsettled and new debts, application of bankruptcy proceedings, and other techniques. In Poland, the government thus deliberately left the private sector to cope with payment arrears on its own, and after some time enterprises and banks began to withhold loans from debtors. In Hungary, there was an attempt to apply a rigorous bankruptcy legislation, but the judicial system was soon overwhelmed with bankruptcy applications, and it became clear that the debts had to be settled outside the courts on a voluntary basis. Clearly, the public sector has to lead by example, but the settling of its payment arrears has to be accomplished without jeopardising monetary stability, i.e., by issuing bonds or writing off the debts against tax arrears owed by suppliers.

The problem of payment arrears illustrates that financial contracts are not, by their very nature, self-enforcing. Creditors may seek a higher rate of interest or some form of collateral from borrowers without a good credit rating as a compensation for greater credit risk, but these insurance mechanisms can create additional problems. Higher interest rates increase the risk of repayment via the negative selection mechanism, because it is largely borrowers with more risky 
projects that are prepared to pay higher interest rates. In order for the real estate and financial instruments really to serve the purpose of collateral, they should be easily marketable, which requires liquid secondary markets, good ownership records, and a legislative framework and judicial practice that facilitate the transfer of property rights. If these conditions are not met, it will be difficult for creditors to collect on the debts they are being owed, which will hold up the economic growth and increase the vulnerability of the financial system. In particular, when financial market infrastructure is weak, banks deal mainly with large and well-established firms. And when large firms get into financial difficulties - as shown by Asian and Latin American experience - it is hard for the banking system to avoid a crisis. Orderly property relations, efficient bankruptcy legislation and procedures, the development of secondary financial markets, and the development of real estate markets thus should be understood as basic preconditions not only for the development of the financial markets, but also for general economic development.

\section{Replacing the national currency?}

In approaching the issue of financial market development, Croatia, like other small open economies, faces a fundamental dilemma: Does it pay to retain the national currency or is it more efficient to introduce a global currency like the euro? According to the literature on optimum currency areas, Croatia could benefit from joining the euro zone: it has a highly open economy, relatively diversified industrial base, relatively mobile capital and labour and a high degree of economic interdependence with euro zone countries. Changes in the kuna exchange rate can therefore only to a limited extent absorb the external economic disturbances, most of which originate in the euro zone. Another potential benefit of euroisation is that close to $80 \%$ of financial contracts (and some two-thirds of savings) are already denominated in foreign currencies or indexed to the deutsche mark. Any depreciation of the kuna vis-à-vis the euro thus creates financial difficulties for net debtors (the corporate and public sectors), and threatens the overall financial stability.

On the negative side, the introduction of the euro would remove only the exchange rate risk, but not other risks (sovereign, market, and credit risks), so that interest rates and bond spreads for Croatian debtors would not necessarily converge to the euro zone levels. Foreign creditors would still seek a risk premium because of the lack of trust in the stability of the Croatian corporate and banking sectors, the possible inconsistency of fiscal and monetary policies, or simply because of the trends in the emerging markets from which Croatia could not disassociate itself. The loss of seignorage revenue would also be non-negligible, despite the firm monetary policy followed since 1994. ${ }^{15}$ In addition, the ability of the Croatian National Bank to provide lender-of-last-resort facilities would be limited. However, this limitation also exists in the current exchange regime, and thus, strictly speaking, cannot be considered an additional cost of euroisation. More importantly, the loss of monetary independence would imply less room for using interest rate policy for domestic anti-cyclical purposes. If, for example, the euro zone economies began to overheat and Croatia had only just begun to recover from a recession, an increase in euro zone interest rates could throw the Croatian economy back into recession. However, given the stage of development of the Croatian corporate sector and financial markets, this cost of euroisation would probably not be large initially, as real economic trends are still relatively insensitive to interest rate changes.

In this context, one should distinguish between unilateral euroisation and the process of joining the European Monetary Union. The establishment of euro-based currency boards and similar arrangements in Bulgaria, Bosnia and Herzegovina, Kosovo, and Montenegro amounts to a de facto unilateral euroisation. In contrast, EMU is part of the whole body of EU law, which implies that countries cannot apply and qualify for admission to EMU until they belong to the EU and demonstrate - after participating for up to three years in the Exchange Rate Mechanism II (ERM II) - that they satisfy the Maastricht convergence criteria on price and exchange rate stability, interest rates, and public sector finances.

\footnotetext{
${ }^{15}$ The loss of seignorage should be calculated as the discounted present value of the seignorage revenue over the next 5-10 years, i.e., from the date the euro is introduced, to the date when Croatia would officially join the European Monetary Union (EMU).
} 
Since Croatia has already opted for the euro by adopting the deutsche mark as a de facto unit of account and an almost universal store of value, the question of the formal adoption of the euro is just a matter of time. Nonetheless, given the political and economic risks associated with unilateral euroisation - in particular, the likely delay in accession to the EU, and the costs of euroisation in the presence of underdeveloped financial markets - it would seem far more efficient to follow the regular accession procedures. Moreover, this approach would enable Croatia to achieve real and nominal convergence within a realistic time frame, whereas unilateral euroisation would force the economy to adjust costs and prices practically overnight in order to maintain competitiveness.

\section{Role of foreign direct investment}

Since the 1994 Mexican crisis, there has been a widespread belief that the inflows of short-term capital are undesirable for stable economic development, while the inflows of foreign direct investment are desirable. According to this view, FDI inflows bring in advanced technology and managerial skills, open up the access to foreign markets, and stay more or less "bolted down" once they enter the country. In contrast, short-term capital flows are triggered by speculative motives differences in interest rates and exchange rate expectations, and implicit government guarantees for corporate and bank liabilities - and therefore have a tendency to flee the country at the first sign of instability, leading to the boom and bust cycles in financial markets and the real sector.

Recent research indicates, however, that capital inflows tend to take the form of FDI in countries that are riskier, less financially developed, and have weaker institution, while short-term capital flows predominate in countries that are less risky, more financially developed and have stronger institutions. ${ }^{16}$ These correlations have been explained by the fact that lower growth prospects and higher risks lead companies to prefer more equity and less debt in the composition of their capital. Also, poorly functioning debt and equity markets can make FDI a more efficient way to access capital. The fact that the share of FDI in capital inflows is rising is not bad in itself, but is instead an optimal response to a deteriorating environment.

Since Croatian policy makers have high expectations regarding FDI's role in future development, these conclusions should be taken rather seriously. For example, it is not hard to imagine a situation in which foreign investments start to flow into hotel business, but all inputs are imported instead of being supplied by Croatian firms, contractors and middlemen, while investments are financed by foreign bank loans with implicit government guarantees. Clearly, the expected balance-of-payments, production and employment effects of such investments would be well below expected. These observations do not imply that FDI is undesirable, as there are few alternatives in the medium run for effective transfer of know-how and technology. But the fact that foreign investors are often inclined to avoid local suppliers and contractors indicates that policies directed at expanding the share of FDI are unwarranted. Instead, Croatia should concentrate on improving the environment for investment and the functioning of markets, which will improve the efficiency of overall investment and raise total capital inflows.

\section{Define the role of the state in the economy}

Although the development strategy by itself redefines the role of the state in the economy, it also has to indicate clearly the basic principles for deciding on the scope and mode of public sector involvement in the economy. As the role for the public sector in Croatia has been studied in great detail elsewhere (see Ott et al., 2000a; Schönfelder, 2000; World Bank, 2000), in this paper only some basic hypotheses are outlined. The main principles that are followed are to take into account the comparative strengths and weaknesses of the Croatian economy, and to shift public spending priorities from politically attractive items to some neglected items with a potentially much greater impact on economic growth and the distribution of income.

\footnotetext{
${ }^{16}$ See Hausmann and Fernandez-Arias (2000) and Fernandez-Arias and Hausmann (2000). FDI accounts for only about $12 \%$ of total capital inflows in industrial countries.
} 


\section{Education}

The government can affect economic development primarily through education, which affects not only the creation of human capital, but also the quality of social capital. ${ }^{17}$ Like in other areas of social life, the pressures to advance education systems have become intense in recent years. ${ }^{18}$ In particular, with the rapid development and adoption of information technology, the share of output that is conceptual rather than physical continues to grow. Critical awareness and the ability to hypothesise, to interpret and to communicate are essential elements of successful innovation in a conceptual-based economy. The ability to think abstractly is therefore increasingly important across a broad range of professions. Today's workers must be equipped not only with technical know-how but also with the ability to create, analyse and transform information and to interact effectively with others. It is precisely in these areas that the Croatian educational system, which is based on rote learning rather than problem solving, lags behind.

A second implication of the rising conceptual share of the value added in economic processes is that learning is increasingly becoming a lifelong activity. Formal education - from kindergarten to university - is only a part of the entire educational system, and school credentials are no longer sufficient to ensure success in the workplace. Today's recipients of diplomas expect to have many jobs and to use a wide range of skills over their working lives. In such circumstances, is essential constantly to train and educate employees, managers, and entrepreneurs. The empirical research by James Heckman has shown that learning-by-doing and various forms of on-the-job training create between one-third and one-half of all the work skills in a modern economy (Hackman, 1999). The implication of this finding for the Croatian development strategy is clear: responsibility for providing and financing education should rest not only with the public sector, but in a large part also with the business sector.

During the 1990s, Croatia has by all accounts experienced stagnation in the development of its education system. One consequence has been the observed decline in the rate of high school and university attendance during the 1990s. In addition, the industrial knowledge and culture in general that distinguished the Croatian workforce at the end of the 1980s have not been renewed nor adapted to the requirements of new technology. At the same time, fledgling domestic industries based on new technologies could not absorb the considerable creative potential of young specialists, so that many of them have left Croatia (Working Group, 2000). This problem is even more pronounced in the case of the training of entrepreneurs and managers, which is neglected in both the formal and continuing educational systems. Finally, a major gap in the Croatian educational system is the inadequate training of civil servants (see the discussion below). Against this background, a new educational policy and a more efficient investment in education emerge as key priorities for long-term development. As the proportion of public spending on education in Croatia is about the same as in similar countries (about 5.5\% of GDP), the emphasis in reforms should be on raising the effectiveness of public education rather than simply pouring more money into educational institutions.

\section{Rule of law}

Apart from education, the public sector in Croatia has to improve its performance in some standard tasks of government: preserving public security, protecting property rights, and ensuring the effective functioning of the judiciary. The importance of these tasks cannot be underestimated - it has been argued convincingly that the expansion of organised crime can be explained by the ineffective protection of property rights on the part of the state (Gambetta, 1993). Failing to establish the rule of law has other negative consequences for economic development: the spread of

\footnotetext{
${ }^{17}$ For example, the education system discourages dysfunctional forms of social behaviour and transmits professional rules of behaviour such as the Hippocratic oath in the medical profession, esprit de corps among civil servants, recognition of authorship and methods of research in scientific work, and respect for inventions and innovations in engineering professions.
}

18 This section draws heavily on Greenspan (2000). 
payment arrears (on account of poor legal and financial discipline), the transfer of obsolescent technology (on account of poor protection of intellectual property rights), and the inflow of foreign investments that do little to raise domestic employment and exports (because of uncertain legal environment and poorly functioning financial markets).

The establishment of the rule of law is a long and laborious process that does not attract the media éclat attending the build-up of certain other institutions of market economy (the central bank, a securities exchange). Therefore, it is essential to work out a quality long-term plan for the development of legal institutions, the judiciary and the civil service in general, and to adequately stimulate professionalism in these occupations. In particular, the civil service should be profiled as a separate and respectable profession by transforming the current inert, unmotivated bureaucracy prone to corruption into efficient, enterprising administrators of public goods and services.

\section{Health care, infrastructure, science, technology}

Government's involvement in the provision and financing of health care, the physical infrastructure, science and technology is generally accepted by economists on account of their public goods characteristics: the provision of these goods would be inadequate from the social point of view if left entirely to the private sector. At the same time, it should be recognised that health care, the physical infrastructure, science and technology are not pure public goods (like national defence), so from an efficiency point of view it is both possible and necessary to charge user fees for the provision of these services. It should also be recognised there is no economic or political rationale for the public sector to maintain a monopoly in the provision of these services. Rather, infrastructure services, health care, science and technological development should be provided in conditions of public and private sector competition.

The implications of these principles for the development strategy are two-fold. On the one hand, the government should reduce its role in the financing and provision of these services and shift many of the costs to the final users. On the other hand, the government should become much more involved in the planning and co-ordination of the development of these activities, and in the regulation of competition in the provision and pricing of these services. How can these principles be applied in concrete reform programmes?

- Public sector spending on health care in Croatia was among the highest in the world in 1997, even though the health care standards were not world-class (see Chapter II). This discrepancy between the social costs and benefits of health care services implies the presence of large inefficiencies in the heath care system. At the same time, the cost of health care for individuals presently is much lower than the benefit derived from public health care services (even after adjusting for quality), which has encouraged excessive use of these services. To achieve greater efficiency in the public heath care system and encourage a more rational use of the available services, it is therefore imperative that a larger part of the costs of health care be transferred to the population. At the same time, government agencies should much more effectively supervise the quality and pricing of health care services and co-ordinate the development of health care with the aim of raising standards and encouraging greater efficiency and competition in the provision of health care services.

- According to the indicators analysed in Chapter II, the existing road and energy infrastructure is not a serious obstacle to the rapid development of the Croatian economy. Accordingly, future financial involvement of the public sector in these infrastructure services could be reduced and re-focused on the maintenance and achievement of greater efficiency in public road and utility companies. The state of the railway, port and water supply infrastructure is by all accounts unsatisfactory. One source of inefficiency is weak corporate governance in public infrastructure companies, so the government should without delay restructure these companies and strengthen its supervisory role. This is largely a matter of political will; the techniques of restructuring railway, port and water supply companies are well-known and readily available internationally. However, significant new investment is also needed to upgrade the railway, port and water supply infrastructure. Give the lack of domestic resources, such investment can only come from foreign strategic investors, so partial privatisation of the infrastructure is unavoidable. 
- Regarding development of science and technology, the economic rationale for government financing is justified in the case of fundamental research but not in the case of applied research, as only the private sector has an incentive to organise such research efficiently and finance it adequately. Despite the relatively large number of scientists and engineers in Croatia, the productivity and commercial effectiveness of scientific research is low, as indicated by the number of scientific publications and registered industrial patents (see Chapter II). Government agencies should therefore encourage greater productivity of scientists and engineers on its payroll, in particular, by exposing universities and scientific institutions to greater domestic and international competition and consistently applying the principle of meritocracy in promotions. In addition, the legal framework for the protection of patent rights and other intellectual property rights needs to be significantly strengthened so as to encourage the transfer of advanced technologies from abroad. The rapid adoption of new information technology also needs to be encouraged, for example, by eliminating customs duties on imports of computer hardware and software, and allowing rapid depreciation of computer equipment and information technology for tax purposes.

In conclusion, it would be wrong to reduce the issue of government's involvement in health care, the physical infrastructure, science and technology to a mere question of budgetary resources for these activities. In many cases, public sector expenditure on these activities should be reduced, not increased. Key questions are how to use budgetary resources more efficiently, how to engage the private sector and introduce efficient corporate governance systems in the public sector, and how to expose these activities to greater competition.

\section{Maintain macroeconomic stability}

In the late 1980s, a broad consensus emerged in the economics profession on the need to maintain stable macroeconomic policy as a basic precondition for successful long-term development (see Williamson, 1990 and 1997; Waelbroeck, 1998). The crisis in the emerging market economies in 1997-98 did not upset this consensus, but it was shown that, in the conditions of the globalisation of production and financial flows, a good macroeconomic policy could not guarantee economic stability and development without structural and institutional reforms. In other words, macroeconomic policy is a necessary but not sufficient condition for the achievement and maintenance of economic stability and development. If, for example, the legal system is weak, firm monetary and fiscal policies will not be able to halt the growth of indebtedness. Macroeconomic policy, then, is not a solution for structural problems, but can only be a catalyst of structural reforms. And in order really to facilitate the implementation of structural reforms, macroeconomic policy has to be stable and consistent.

The record of the transition economies in Central Europe provides an illustration. Growth in these economies has benefited in particular from low inflation, low taxation, the absence of restrictive measures of foreign exchange and import controls, and the absence of price controls in the goods, services and factor markets (Havrylyshyn et al., 1998; Wyplosz, 2000). Considering structural factors, growth in the transition economies has benefited from a favourable investment climate, government credibility, political stability, and the absence of corruption (EBRD 1999; Havrylyshyn et al., 1999;). These findings are often neglected in debates about economic policy in Croatia. Many Croatian economists still believe that an active macroeconomic policy and a passive stance toward structural reforms can generate faster economic growth and development than the policies that emphasise a stable macroeconomic framework and deep structural reforms.

\section{Exchange rate and monetary policy}

This section further elaborates the argument that an active exchange rate policy cannot be used as a springboard for economic growth and development, and would actually have very harmful consequences in Croatia. The experience of Central European transition economies provides a useful reference.

At the beginning of the transition, the Czech Republic had no foreign debt. Since the official exchange rate was considered overvalued and the export sector uncompetitive, there were strong arguments for a large devaluation. The devaluation proved beneficial for the export industries, but it delayed serious restructuring on account of the temporary gain in competitiveness; moreover, a 
new export-oriented private sector did not develop because existing large firms retained their dominant position (Carlin and Landsemann, 1997). After the initial devaluation, the exchange rate was more or less fixed. This in turn led to large capital inflows (including the short-term portfolio capital) and an appreciation of the currency. In 1998, a large current account deficit developed, the koruna came under pressure and had to be devalued, and the economy plunged into recession.

In contrast, Poland and Hungary entered the transition with large foreign debts and were not in a position to stimulate exports with devaluation. But at the same time, the exchange rate was never fixed; instead, a certain flexibility was maintained in exchange rate policy, forcing the private sector to factor the exchange rate risk into its calculations and thus abstain from heavy foreign borrowing, and slowing the inflows of short-term capital. Hungary and Poland also systematically carried out structural reforms, which forced the corporate sector to restructure and encouraged the development of the new private sector, leading over time to large improvements in productivity (Landesmann, 2000).

Croatia shares the unfavourable conditions of Poland and Hungary (large foreign debt) as well as the Czech Republic (neglect of structural reforms, domination of big firms and absence of a new private sector). More importantly, Croatian banks are considerably more exposed to the foreign exchange risk. On the asset side, $80 \%$ of banking system loans are believed to be indexed to the euro (i.e., the deutsche mark), so a large devaluation would undoubtedly lead to increased incidence of non-performing loans and loan defaults. On the liability side, two-thirds of M4 in Croatia is made up of foreign currency deposits, as against $8 \%$ in Czech Republic, $20 \%$ in Poland, and $27 \%$ in Hungary. Given the history of currency substitution and banking instability, it is possible that a large devaluation of the kuna would trigger a run on these deposits, further exposing the banks. Moreover, the public sector would face significantly higher costs of servicing its external debt.

These observations do not imply that the maintenance of the exchange-rate indexation is desirable in the long run. In particular, so long as monetary and exchange rate policies are hamstrung by the indexation of loans to the exchange rate, it is not possible permanently to restructure the corporate and banking sectors. One possible solution is for all financial contracts signed after the passing of a suitable law to be declared invalid if they contain an indexation clause. ${ }^{19}$ In this way, the exchange rate indexation would gradually cease to have any effect, since existing contracts that contain the clause would not be renewed.

Another possibility is to restrict the legal validity of the clause to only relatively small changes in the kuna-euro exchange rate (e.g., of $10-15 \%$ a year). This margin would provide room for a somewhat more flexible exchange rate policy, but without the severe balance sheet repercussions noted above. At the same time, the banks, the enterprises, and the population would begin to account for the exchange rate risk. With determined fiscal adjustment and in the absence of major external shocks, such a regime could calm down expectations of continued depreciation and inflation, thus paving the way for an orderly and gradual transition toward the EU and EMU.

Of particular importance for the maintenance of stability in this transitional period will be the switch to a monetary regime based of inflation targeting. ${ }^{20}$ The main advantage of such regime is that monetary policy is given the task of achieving a clear nominal objective. Unlike targeting a particular range for the nominal exchange rate, the central bank has greater influence and instrument flexibility in achieving an inflation target (see Blejer et al., 2000). A clear nominal target can also favourably affect inflation expectations, and shift the exchange rate risk to its proper place, i.e., with the banks and the private sector rather than the government. The advantage of a targeted inflation regime also lies in its technical implementation not depending on trends in monetary aggregates, which are very unstable in periods of rapid structural change and the development of financial markets. However, experience to date from Poland and the Czech

\footnotetext{
19 A similar provision was included in Argentina's 1991 Convertibility Law. The exchange-rate indexation of private debts is not allowed in most other Latin American and almost all the transition economies.

${ }^{20}$ Greater exchange rate flexibility in Poland and the Czech Republic in the last three years has been accompanied by a monetary policy whose basic aim is to attain a targeted level of inflation. Poland for example announced for 2000 an inflation target of 5.4-6.8\%, and the Czech Republic of 2-4\%.
} 
Republic indicates that there are considerable technical requirements in determining, monitoring and realising the targeted rate of inflation, especially when the process of inflation is not well understood and statistics are unreliable (BIS, 2000).

\section{Tax and investment policy}

Debates about development policy in Croatia, including this paper, have so far paid less attention to tax than to exchange rate and monetary policy. This is not an oversight, but the reflection of a broad consensus among experts that the tax system built in Croatia during the 1990s was economically sound, consistent and transparent (see IMF, 2000a; Ott et all, 2000a). Changes in the tax system introduced since early 2000 have, however, vitiated many of its good qualities. The development strategy is thus unnecessarily faced with the question of tax reform, or of returning to solutions that in most case (VAT, excise, personal and corporate income tax) already existed. Against this background, it is necessary to refer once again to the desirable characteristics of a good tax system:

- Allocative neutrality, i.e., the minimising of the distortions that taxes introduce in the allocation of economic resources, especially of labour and capital;

- Stability, which enables taxpayers to plan business decisions over the longer term, and allows tax authorities to run a stable budgetary policy;

- Administrative simplicity, which reduces compliance and collection costs;

- Transparency, which enables taxpayers clear insight into the economic and political factors that affect the level at which their tax burdens are set;

- Flexibility, which assists in the maintenance of macroeconomic stability during the course of business cycle by means of built-in automatic stabilisers;

- Equity of treatment of taxpayers in the same position (horizontal equality).

For the development strategy, the first four characteristics are particularly important. Differentiated tax rates and exemptions introduced in the Croatian tax system in 2000 clearly violate these principles, and recall the tax solutions from the time of socialism, when differentiated taxes were used to redistribute earnings among the different branches of the economy. At that time, the markets for goods and services were still subject to numerous controls, while the markets for capital and labour were rudimentary. Accordingly, enterprises faced different distortions in output and input prices, which resulted in different rates of profitability and hence different wages for workers employed in different industries. Since such income differentials compromised the political legitimacy of the socialist government, differentiated corporate taxes were applied to level out the operational performance ex post, instead of levelling out the operational conditions for all firms ex ante (Mihaljek, 1999). In such circumstances, firms were constantly bargaining with the government to obtain tax breaks, and the total tax burden had no relationship with the performance of a firm or with the legal tax obligation.

Similar forms of corporate behaviour are visible in Croatia even today. Industries founded on differentiated tax structures - machine building, shipbuilding, agriculture, tourism - generally oppose the introduction of unified tax rates that preserve allocative neutrality and simplicity, maintain stability and transparency, and, above all, eliminate rents and encourage competition. By re-introducing differentiated taxes, the authorities have effectively condoned such rent-seeking behaviour and avoidance of serious corporate restructuring in industry.

Recent attempts to introduce special investment incentives (tax holidays and amnesties, special economic and customs zones etc.) are another cause for concern. Empirical research has shown that, over the medium and long term, such incentives do not raise the volume of domestic and foreign investment, but rather reduce the total tax revenue and lead to efficiency losses on account of distortions they introduce (see Arbutina, 1999; and Mihaljek, 1993). Moreover, the use of investment incentives generally violates WTO rules. The experience of Hong Kong since the 1960s and Ireland in the 1990s indicates that the best tax framework for encouraging investment is a neutral, stable, and transparent system with unified and low tax rates. 


\section{AN ILLUSTRATIVE SCENARIO OF LONG-TERM GROWTH}

This chapter addresses one of the key analytical issues for the elaboration of a long-term development strategy: How fast can the Croatian economy actually grow? More precisely, what rate of real growth should be achieved for the per capita GDP of $\$ 4,800$ from 1999 to be doubled in the next 10-15 years, and can the Croatian economy realistically be expected to sustain that growth rate over the long term?

To answer the first question, Table 6 calculates the growth rates that it would be necessary to achieve for the real per capita GDP to double in the next 10-15 years. For example, if the goal is to double per capita GDP by 2010, the average annual growth rate of real GDP would have to be $6.8 \%$; if the goal is to double per capita GDP by 2015 , the growth rate of real GDP would have to be $4.9 \%$. For illustration, consider the growth path at an average annual rate of $5 \frac{1}{2} \%$. At this rate, it would be possible to double per capita GDP in 13 years, and to attain $75 \%$ of the per capita GDP level of the less developed European countries in the next 30 years (Figure 7).

Table 6. Scope for doubling of Croatia's real per capita GDP, 2010-15

\begin{tabular}{|c|c|c|}
$\begin{array}{l}\text { Average annual } \\
\text { growth rate of } \\
\text { real GDP (\%) }\end{array}$ & $\begin{array}{l}\text { Target year for } \\
\text { doubling per } \\
\text { capita GDP }\end{array}$ & $\begin{array}{l}\text { Ratio of per } \\
\text { capita GDP in } \\
\text { Croatia and } \\
\text { Europe in target } \\
\text { year (\%) }\end{array}$ \\
\hline 6.8 & 2010 & 51 \\
6.3 & 2011 & 50 \\
5.9 & 2012 & 49 \\
5.5 & 2013 & 48 \\
5.2 & 2014 & 47 \\
4.9 & 2015 & 45 \\
\hline
\end{tabular}
Source: Author's calculations.
1/ Target GDP of US\$10,000.
2/ Relative to the projected average for smaller European economies:
Greece, Israel, Ireland, Spain and Portugal.

To answer the second question it would be necessary to estimate the aggregate production function of the Croatian economy. As this would require substantial additional empirical research and many data series are not available, three simpler analytical methods are used: the Hodrick-Prescott filter, the incremental capital output ratios, and projections based on parameters from an estimated convergence equation. The results are encouraging, as all three methods give a similar answer the potential growth rate of the Croatian economy is between $5.4 \%$ and $6.2 \%$.

The Hodrick-Prescott filter separates the cyclical component from the trend of a time series. Since the application of this method is sensitive to the initial and final observations, the period chosen for analysis is from the first quarter of 1994 to the second quarter of 1998. The potential growth rate during this period was between $5.9 \%$ and $6.2 \%$, i.e., higher than the desired long-term growth rate of $5 \frac{1}{2}$ (Figure 7). One should stress that growth during 1994-98 was led by private consumption and investment in reconstruction, and was therefore not sustainable in the long run. Nonetheless, an estimate of the potential growth from this period is useful, as it probably represents an upper limit to the rates that could be achieved over the long term, when the main sources of growth are expected to become net exports and capital investment. 


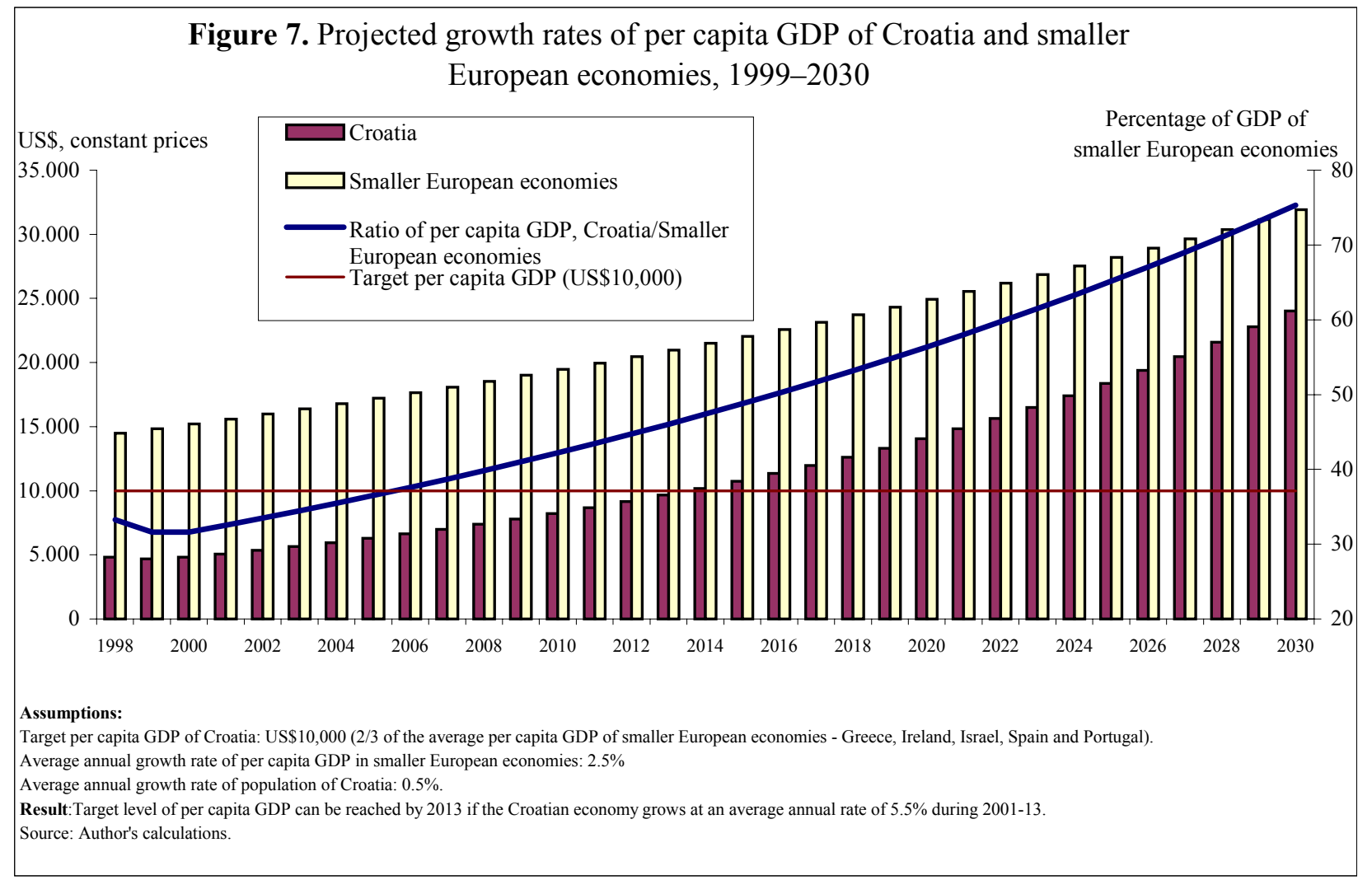

Figure 8. Actual and potential growth rate of GDP in Croatia, 1994-98.

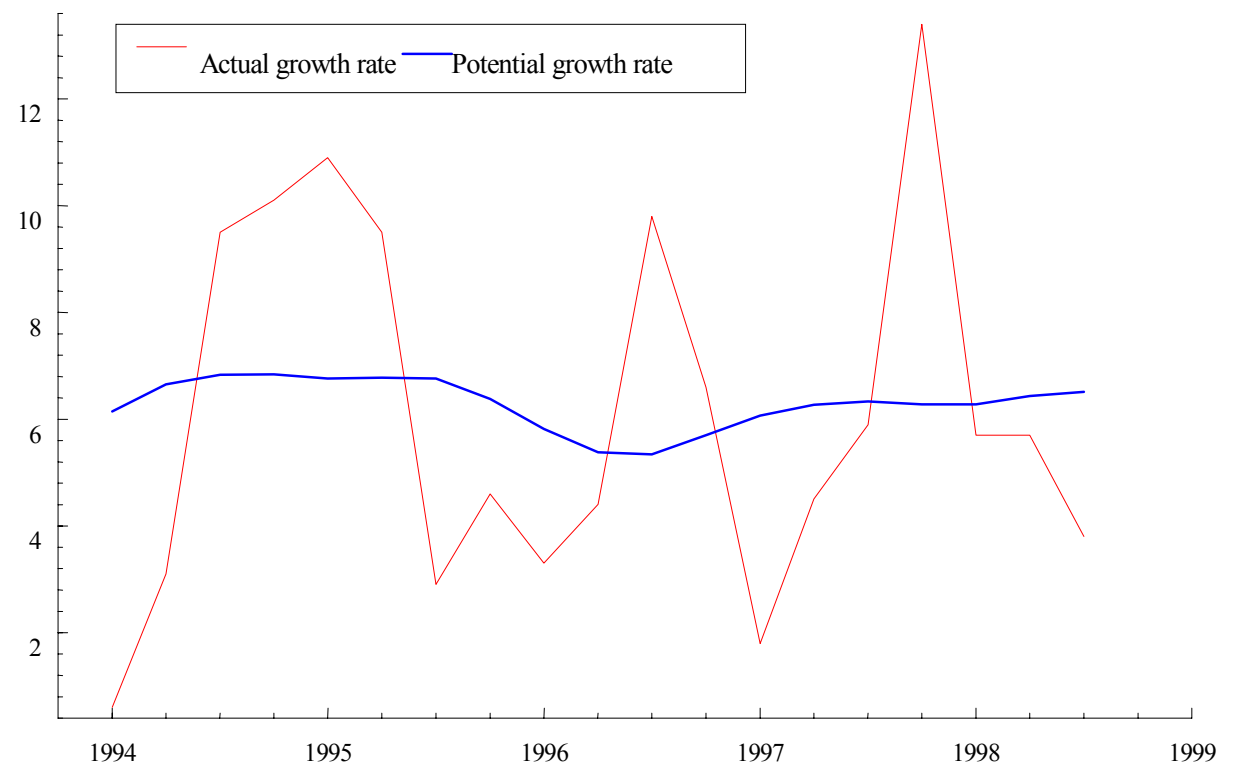


The concept of incremental capital output ratios (ICOR) is based on a model where the growth rate depends on the rate and efficiency of investment. ${ }^{21}$ During 1994-98, with an average annual growth of $5 \frac{1}{2} \%$ and an investment rate of $21.7 \%$, the ICOR was on average equal to 4.6 , with annual variations of $2.6-9.3 \%{ }^{22}$ This value can be used for an illustration of the best case (higher rate and efficiency of investment) and worst case (lower rate and efficiency) scenarios (Table 7). If the average of these two scenarios is taken as a baseline projection, it appears that, by maintaining the current investment rate of $25 \%$ and investment efficiency achieved during 1994-98, it is possible to achieve real GDP growth of approximately 5.4\% per annum. With a somewhat higher investment rate of $27 \%$ GDP (which can be realistically expected in the coming period) and the same efficiency of investment, the potential growth rate would rise to $5.9 \%$.

Table 7. Long-term growth as function of rate and efficiency of investment

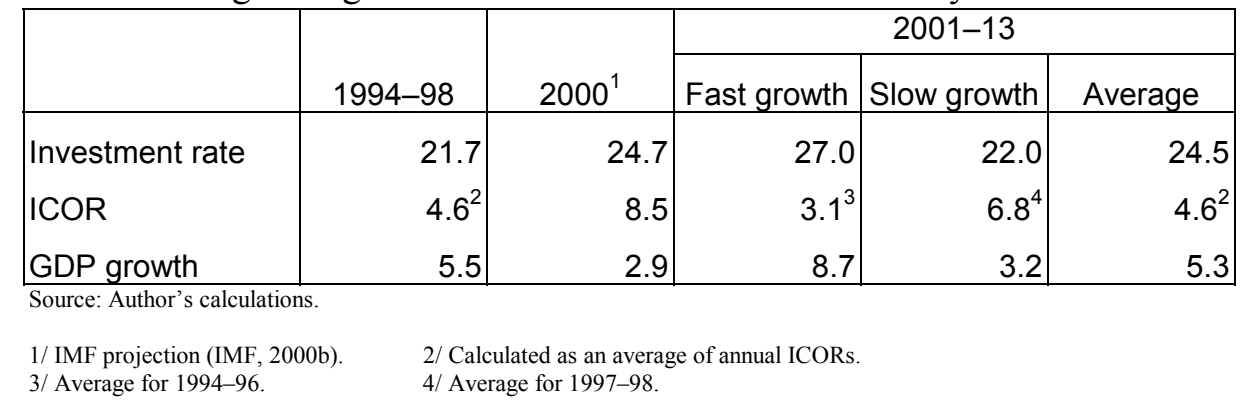

Finally, the potential growth rate can be approximated with the aid of parameters estimated for an econometric growth model of similar economies. Gomulka (2000) estimated the following growth convergence equation for twenty medium-developed market economies in Western Europe, Latin America and East Asia for the post-Second World War period:

$\mathrm{g}=-2.22+0.195(\mathrm{I} / \mathrm{Y})+5.63 \log _{10}\left(\mathrm{y}^{\text {usa }} / \mathrm{y}\right)-5.92 \log _{10}(1+\pi)$

$(-3.6) \quad(7.9) \quad(14.5) \quad(-6.8)$

where $g$ is the growth rate of real GDP, $I / Y$ is the rate of investment, $y^{u s a} / y$ is the ratio of per capita GDP in the United States and a given country (with the GDPs being expressed in terms of purchasing power parity), and $\pi$ is the rate of inflation (measured by the GDP deflator); the values of the t-statistics are shown in brackets, and the coefficient of determination was $\mathrm{R}^{2}=0.80$.

The parameters from this regression can be used to illustrate a growth path based on arbitrary but plausible values of the rate of investment, income gap, and inflation. One scenario is shown in Table 8. Assuming that the rate of investment stays at the current level of $24-25 \%$ of GDP, that the income gap vis-à-vis the United States is reduced by $10 \%$ (to $400 \%$ from $440 \%$ ), and that inflation declines to $3 \%$ in the long term, the potential growth rate of the Croatian economy would come to about $5.9 \%$ a year. This exercise is not intended to provide precise projections of the growth rate in the next 10-15 years, but to approximate the potential trend growth rate in Croatia on the basis of the broad and long-term experience of a group of countries thought to be representative of medium-developed and market-based economies.

${ }^{21}$ ICOR is the relation between the rate of investment (gross fixed investment as a percent of GDP) and the growth rate of real GDP. A lower ICOR implies greater investment efficiency (not taking into account negative growth rates), because a unit increase in output is achieved with less investment.

${ }^{22}$ For illustration, the ICOR in Korea, Malaysia, Thailand and Indonesia was 4.1-4.8 before the 1997-98 crisis, and 2.9-8.5 after the crisis (JP Morgan, 2000). 
Table 8. Long-term growth as a function of investment, income gap and inflation

\begin{tabular}{|c|c|c|c|c|c|c|}
\hline & g & $1 / Y$ & $\mathrm{y}^{\mathrm{usa}} / \mathrm{y}^{\mathrm{hr}}$ & $\pi$ & $\Delta \mathrm{D} / \mathrm{Y}$ & $D / Y$ \\
\hline 2001 & 6.1 & 25.0 & 4.3 & 4.5 & 3.5 & 33.0 \\
\hline 2002 & 6.3 & 26.0 & 4.2 & 4.0 & 3.5 & 34.0 \\
\hline 2003 & 6.3 & 26.0 & 4.2 & 3.5 & 3.4 & 35.0 \\
\hline 2004 & 6.0 & 25.0 & 4.1 & 3.5 & 3.3 & 35.0 \\
\hline 2005 & 6.0 & 25.0 & 4.1 & 3.5 & 3.3 & 35.0 \\
\hline 2006 & 5.8 & 24.0 & 4.0 & 3.0 & 3.1 & 35.0 \\
\hline 2007 & 5.8 & 24.0 & 4.0 & 3.0 & 3.1 & 35.0 \\
\hline 2008 & 5.8 & 24.0 & 4.0 & 3.0 & 3.1 & 35.0 \\
\hline 2009 & 5.8 & 24.0 & 4.0 & 3.0 & 3.1 & 35.0 \\
\hline 2010 & 5.8 & 24.0 & 4.0 & 3.0 & 3.1 & 35.0 \\
\hline 2011 & 5.8 & 24.0 & 4.0 & 3.0 & 3.1 & 35.0 \\
\hline 2012 & 5.8 & 24.0 & 4.0 & 3.0 & 3.1 & 35.0 \\
\hline 2013 & 5.8 & 24.0 & 4.0 & 3.0 & 3.1 & 35.0 \\
\hline 2001-13 & 5.9 & 24.5 & 4.1 & 3.3 & 3.2 & 34.8 \\
\hline
\end{tabular}

The last illustration relates to the budget deficit $(\Delta \mathrm{D} / \mathrm{Y})$ as function of the growth of rate $(\mathrm{g})$, the rate of inflation $(\pi)$ and the total debt of the public sector is $(D / Y)$. The relation between these variables is described by Equation 2, used inter alia in discussions about convergence to the Maastricht criteria for joining the EMU.

$$
\frac{\Delta D}{Y}=(\pi+g) \frac{D}{Y}
$$

The last two columns of Table 8 show the values of the budgetary deficit of Croatia that are consistent with the projected growth rates of real GDP and inflation, assuming that the level of public debt gradually increases to $35 \%$ of GDP in order to finance the remaining structural reforms of the pensions and healthcare systems, labour markets and state-owned enterprises. With an annual inflation of $3 \%$ and growth of $5-6 \%$, Croatia would have enough room to take on additional debts and still satisfy the Maastricht criteria on the budgetary deficit (at most $3 \%$ of GDP) and level of public debt (at most $60 \%$ of GDP). 


\section{REFERENCES:}

Adelman, Irma, "Fifty Years of Economic Development: What Have We Learned." Paper presented at the World Bank Annual Bank Conference on Development Economics Europe 2000, Paris, June 26-28, 2000. http://www.worldbank.org/research/abcde/eu_2000/papers_eu2.html

Adelman, Irma, "Society, Politics, and Economic Development: Thirty Years After." In John Adams and Francesco Piglariu, eds. Economic Growth and Change, Chelthenham: Edward Elgar, 1999.

Adelman, Irma i Cynthia Taft Morris, Society, Politics, and Economic Development: A Quantitative Approach. Baltimore: Johns Hopkins University Press, 1967.

Arbutina, Hrvoje, "Reforma poreznih sustava u tranzicijskim državama Srednje i Istočne Europe." Financijska praksa, Vol. 23, No. 3/1999, 233-54.

Bank for International Settlements (BIS), 70 th Annual Report: 1 April 1999-31 March 2000. Basel: BIS, June 2000. http://www.bis.org/publ/index.htm

Begg, David, "Monetary Policy in Central and Eastern Europe: Lessons After Half a Decade of Transition.” IMF Working Paper No. 96/108, September 1996.

Begg, David, and Richard Portes, "Enterprise Debt and Economic Transformation: Financial Restructuring in Central and Eastern Europe." In C. Mayer and X. Vives, Capital Markets and Financial Intermediation. Cambridge: Cambridge University Press, 1993, 230-61.

Berend, Ivan T., "From Plan to Market, From Regime Change to Sustained Growth in Central and Eastern Europe." United Nations Economic Commission for Europe, May 2000.

http://www.unece.org/ead/ead_h.htm

Bićanić, Ivo i Katarina Ott, The Unofficial Economy in Croatia: Causes, Size and Consequences. Occasional Paper No. 2, Institut za javne financije, Zagreb, studenog 1997.

http://www.ijf.hr/ocpapers/op-3.htm

Blejer, Mario, Alain Ize, Alfredo Leone, and Sérgio Werlang (eds.), Inflation Targeting in Practice: Strategic and Operational Issues and Application to Emerging Market Economies. Washington: IMF, 2000. http://www.imf.org/external/pubs/ft/seminar/2000/targets/stratop.htm

Carlin, Wendy, and Michael Landesmann, "From Theory into Practice? Corporate Restructuring and Economic Dynamism in Transition Economies." Research Report of the Vienna Institute for Comparative Economic Studies, No. 240, August 1997.

Claessens, Stijn, "How Does Foreign Entry Affect the Domestic Banking Market?" World Bank Policy Research Working Paper No. 1918, May 1998.

http://www.worldbank.org/html/dec/Publications/Workpapers/WPS1900series/wps1918/wps1918. pdf

European Bank for Reconstruction and Development, Transition Report 1999: Ten Years of Transition. London: EBRD, 1999.

Feige Edgar and Katarina Ott, eds., Underground Economies in Transition: Unrecorded Activities, Tax Evasion, Corruption and Organized Crime. Aldershot: Ashgate, 1999.

Fernández-Arias, Eduardo, and Ricardo Hausmann, "Is FDI a Safer Form of Financing?" Working Paper No. 416, Interamerican Development Bank, March 2000.

http://www.iadb.org/oce/324.cfm

Fitch IBCA, Republic of Croatia: Sovereign Report, June 2000. www.fitchibca.com

Gambetta, Diego, The Sicilian Mafia: The Business of Private Protection. Cambridge: Harvard University Press, 1993.

Garibaldi, Pietro, and Paulo Mauro, "Deconstructing Job Creation." IMF Working Paper No.

99/109, August 1999. http://www.imf.org/external/pubs/ft/wp/1999/wp99109.pdf 
Goldberg, Linda, Gerard Dages, and Daniel Kinney, "Foreign and Domestic Bank Participation in Emerging Markets: Lessons from Mexico and Argentina." Federal Reserve Bank of New York, Economic Policy Review, September 2000.

http://www.ny.frb.org/rmaghome/econ_pol/800dage.pdf

Gomulka, Stanislaw, "Macroeconomic Policies and Achievements in Transition Economies, 1989-1999." United Nations Economic Commission for Europe, May 2000.

http://www.unece.org/ead/ead h.htm

Gorupić, Drago, "Prilog raspravi o razvojnoj koncepciji SR Hrvatske" (A Contribution to the Debate on the Concept of Development of the SR Croatia). Ekonomski institut - Zagreb, 1982.

Government of the Republic of Croatia, Program rada Vlade Republike Hrvatske za razdoblje 2000-2004 godine (Work Programme of the Government of Croatia for the Period 2000-2004). Zagreb, 8. veljače 2000. http://www.vlada.hr/dokumenti.html

Greenspan, Alan, "Revolution in Information Technology and its Implications for Key Government Policies." BIS Review No. 21, 10 March 2000. http://www.bis.org/review/index.htm

Hackman, James, "Policies to Foster Human Capital." Paper presented at the Aaron Wildavsky Forum, University of California at Berkeley, 1999.

http://lily.src.uchicago.edu/papers/labor/Wildavsky.pdf

Hausmann, Ricardo, and Eduardo Fernández-Arias, "Foreign Direct Investment: Good Cholesterol?" Working Paper No. 417, Interamerican Development Bank, March 2000. http://www.iadb.org/oce/324.cfm

Havrylyshyn, Oleh, Ivailo Izvorski, and Ron van Rooden, "Recovery and Growth in Transition Economies 1990-97: A Stylized Regression Analysis" IMF Working Paper No. 98/141, September 1, 1998. http://www.imf.org/EXTERNAL/PUBS/CAT/longres.cfm?sk\&sk=2752.0

Havrylyshyn, Oleh, Thomas Wolf, Julian Berengaut, Marta Castello-Branco, Ron van Rooden, and Valerie Mercer-Blackman, Growth Experience in Transition Countries, 1990-98. IMF Occasional Paper No. 184, 1999. http://www.imf.org/external/pubs/nft/op/184/index.htm

Hawkins, John, and Dubravko Mihaljek, "The Banking Industry in the Emerging Market Economies: Competition, Consolidation and Systemic Stability." Forthcoming in BIS Papers, 2001.

Hellman, Joel S., Geraint Jones, Daniel Kaufmann, and Mark Schankerman, "Measuring Governance, Corruption, and State Capture: How Firms and Bureaucrats Shape the Business Environemtn in Transition Economies." World Bank Policy Research Working Paper No. 2312, April 2000. http://wbln0018.worldbank.org/Researchlworkpapers.nsf/AllDocuments?SearchView

Institute of Public Finance, Razvoj porezne uprave u Republici Hrvatskoj (Development of Tax Administration in Croatia). Financijska praksa, Vol. 22, No. 1-2/1998.

International Monetary Fund, Republic of Croatia: Selected Issues and Statistical Appendix. IMF Staff Country Report No. 00/22. Washington: IMF, February 2000a.

http://www.imf.org/external/pubs/cat/longres.cfm?sk\&sk=3439.0

International Monetary Fund, Republic of Croatia: Staff Report for 1999 Article IV Consultation. IMF Staff Country Report No. 00/7. Washington: IMF, January 2000b. http://www.imf.org/EXTERNAL/PUBS/CAT/longres.cfm?sk\&sk=3384.0

JP Morgan, Asian Financial Markets, Second Quarter 2000. Singapore: JP Morgan, April 28, 2000 .

Kesner-Škreb, Marina, "Neslužbeno gospodarstvo i razvoj” (Unofficial Economy and Development). Financijska praksa, Vol. 21, No. 1-2/1997.

Kesner-Škreb, Marina, "State Intervention as an Incentive for Growth in Market Economies." Institute of Public Finance Occasional Paper No. 1, Zagreb, January 1997.

Kuhner, Christoph, "Rating Agencies: Are They Credible? Insights Into the Reporting Incentives of Rating Agencies in Times of Enhanced Systemic Risk." University of Munich Working Paper, November 1998. 
Landesmann, Michael, "Structural Change in the Transition Economies since 1989." United Nations Economic Commission for Europe, May 2000. http://www.unece.org/ead/ead h.htm

Malenica, Zoran, "Dvije Hrvatske” (Two Croatias). In Vjekoslav Šmid, ed., Zbornik radova Pravnog fakulteta u Splitu 1999, Split: Pravni fakultet Sveučilišta u Splitu 1999, 387-400.

Mihaljek, Dubravko, "Redoslijed provođenja fiskalnih reformi u gospodarstvima u tranziciji" (Sequencing of Fiscal Reforms in Economies in Ttransition). Financijska praksa, Vol. 23, No. 3/1999, 233-54.

Mihaljek, Dubravko, "Porezna politika i gospodarski razvoj: Iskustva azijskih zemalja" (Tax Policy and Economic Development: Experience of the Asian Countries). Financijska praksa, Vol. 17, No. 6/1993, 511-34.

Ott, Katarina, Marina Kesner-Škreb, Anto Bajo, Predrag Bejaković, i Zoran Bubaš, Ekonomika javnog sektora: Stanje, problemi, i moguća rješenja (Economics of the Public Sector: Current

State, Problems, and Possible Solutions). Newsletter no. 4 of the Institute of Public Finance, 2000. http://www.ijf.hr/newsletter/4.htm

Rostowski, Jacek, "Interenterprise Arrears in Post-Communist Economies." IMF Working Paper No. 94/43, April 1994. http://www.imf.org/EXTERNAL/PUBS/CAT/longres.cfm?sk\&sk=1184.0

Schönfelder, Bruno, "Ökonomische Aspekte der Sozialpolitik im postsozialistischen Südosteuropa.” TU Bergakademie Freiberg Workong paper, May 2000.

Sinclair, Thea, "Tourism and Economic Development: A Survey." Journal of Development Studies, Vol. 34, June 1998, 1-51.

Škreb, Marko, "Izlaganje Guvernera HNB-a u Hrvatskom državnom saboru: Uvod u raspravu o materijalima HNB-a" (Presentation of the Governor of the Croatian National Bank to the Croatian National Assembly: Introduction to the Discussion on the CNB Reports). Zagreb, Hrvatska narodna banka, 12-21. travnja 2000. http://www.hnb.hr/priopc/hpriopc.htm

Štulhofer, "Sociokulturni aspekti neslužbenog gospodarstva: između oportunizma i nepovjerenja" (Socio-cultural Aspects of Unofficial Economy: Between Opportunism and Distrust). Financijska praksa, Vol. 21, No. 1-2/1997.

Tanzi, Vito, and Howell Zee, "Tax Policy for Emerging Markets: Developing Countries." IMF Working Paper No. 00/35, March 2000.

http://www.imf.org/external/pubs/ft/wp/2000/wp0035.pdf

Transparency International, 2000 Corruption Perceptions Index. http://www.transparency.de/documents/cpi/

Waelbroeck, Jean, "Half a Century of Development Economics: A Review Based on the Handbook of Development Economics." World Bank Economic Review, Vol. 12, May 1998. http://www.worldbank.org/research/journals/wber/revmay98/half.htm

Williamson, John, “The Washington Consensus Revisited”, in L. Emmerij, ed., Economic and Social Development into the XXI Century. Washington: Inter-American Development Bank, 1997.

Williamson, John, "What Washington Means by Policy Reform", in J. Williamson, ed., Latin American Adjustment: How Much Has Happened? Washington: Institute for International Economics, 1990.

Working Group of the President of the Republic of Croatia, e-Croatia-Proposal for a Strategy of Information Technology Development in Croatia. Zagreb, 20. Srpnja 2000. http://www.predsjednik.hr/radne skupine/strategija i hrvatske/datoteke/strategija i hrvatske.pdf

World Bank, World Development Indicators 2000. http://www.worldbank.org/html/extpb/wdi2000.htm

World Bank, Hrvatska: Program mjera za gospodarsku reformu i rast (Croatia: Program of Measures for Economic Reform and Growth). Zagreb: IBRD, veljača 2000.

http://www.worldbank.hr/html/links.html 
World Bank, World Development Report 1999/2000: Entering the $21^{\text {st }}$ Century. Washington: World Bank, 1999.

World Tourism Organization, Tourism Highlights 2000, Second Edition, August 2000. http://www.world-tourism.org/

Wyplosz, Charles, "Ten Years of Transformation: Macroeconomic Lessons." Paper presented at the World Bank Annual Bank Conference on Development Economics, Washington, April 2830,1999. http://www.worldbank.org/research/abcde/washington_11/pdfs/wyplosz.pdf 